\title{
Articles
}

\section{RETHINKING POLICE RULEMAKING}

\section{Maria Ponomarenko}

ABSTRACT-For more than sixty years, prominent policing scholars have argued that the way to address the many problems of policing is to treat police departments like all other agencies of government - and to require that they set policy through something like notice-and-comment rulemaking. This paper argues that despite its intuitive appeal, rulemaking is not a particularly apt solution to policing's various ills. Although policing scholars have been right to look to administrative law for ideas on how to govern policing, they have been focused on the wrong set of administrative tools. Instead of looking to the public to regulate the police through rulemaking, a more promising alternative is to create what I call regulatory intermediaries - permanent administrative bodies that can stand in for the public and help regulate the police.

AUTHOR-Associate Professor, University of Minnesota Law School. I am grateful for their many comments and suggestions to Rachel Barkow, Barry Friedman, Rachel Harmon, Richard Revesz, Christopher Slobogin, the participants at the Vanderbilt Criminal Justice Roundtable, as well as the faculty workshop participants at Cardozo Law School, Moritz College of Law at Ohio State, Sandra Day O'Connor College of Law at Arizona State, the University of Michigan Law School, and the Washington College of Law at American University. This article benefited greatly from terrific research assistance by Madelyn Fife and Russell Patterson. 


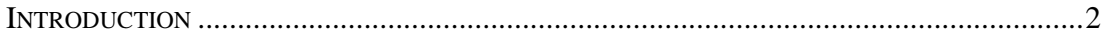

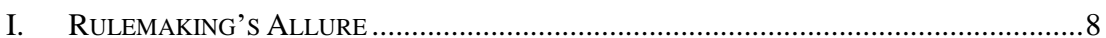

A. The Problems with Policing.......................................................................... 8

B. The Enduring Appeal of Administrative Rulemaking .................................... 13

C. The Conventional Case Against Police Rulemaking........................................ 15

II. Governing Policing Through Administrative RuleS .....................................2 20

A. Why Policing Agencies Adopt Rules (and Why They Don 't) .........................20

B. Requiring Policing Agencies to Write Rules.................................................... 33

C. Determining Which Policies Require Public Input ........................................ 36

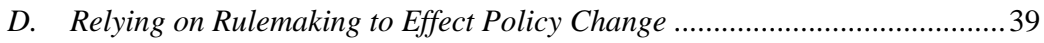

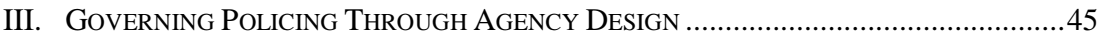

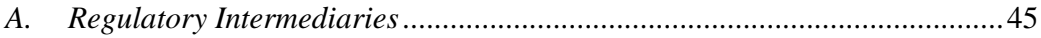

B. Rethinking Local Governance of the Police ....................................................5

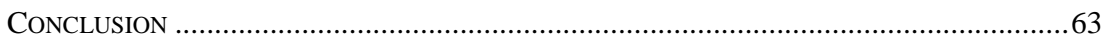

\section{INTRODUCTION}

A police department "is in every sense of the term an administrative agency." Like any other agency, it "makes important policy," and like any other agency, it should be required to formulate this policy "through rulemaking procedure along the line of what is required of federal agencies by the Administrative Procedure Act." 2

Professor Kenneth Culp Davis made this observation in 1969, during what might be described as policing's first "rulemaking moment." Beginning in the mid-1960s, a number of scholars, including Professors Herman Goldstein and Anthony Amsterdam, embraced the idea that policing agencies are agencies like any other-and that like agencies, they should formulate policy through binding rules, with some opportunity for public comment. ${ }^{3}$ Rulemaking, they argued, would address many of the problems with policing that had drawn public scrutiny, from discriminatory

\footnotetext{
${ }^{1}$ KenNETh CUlP DAVIS, DisCRETIONARY JuSTICE: A PRELIMINARY INQUiRY 80 (1969).

2 Id.

3 See Anthony G. Amsterdam, Perspectives on the Fourth Amendment, 58 MinN. L. REv. 349, 42122 (1974) (emphasizing benefits of public rulemaking by the police); Gerald M. Caplan, The Case for Rulemaking by Law Enforcement Agencies, 36 L. \& ConTEMP. ProBs. 500, 502-06 (1971) (same); Herman Goldstein, Police Policy Formulation: A Proposal for Improving Police Performance, 65 MicH. L. REV. 1123, 1130 (1967) (arguing that police rulemaking would enhance the operations and professionalization of individual policing agencies as well as the functionality of the broader criminal justice system); Robert M. Igleburger \& Frank A. Schubert, Policy Making for the Police, 58 AM. B. Ass'N J. 307, 310 (1972) (advocating in favor of police rulemaking); Carl McGowan, Rule-Making and the Police, 70 Mich. L. REV. 659, 676-81 (1972) (same).
} 
enforcement to excessive force. ${ }^{4}$ Two national commissions echoed these observations, ${ }^{5}$ as did the American Bar Association and the American Law Institute, both of which launched projects to develop model rules for the police. ${ }^{6}$

Although the first rulemaking moment largely fizzled by the $1980 \mathrm{~s}-$ due in no small part to the reluctance of policing agencies to conceive of themselves as rulemaking bodies - the idea that policing agencies should operate more like traditional administrative agencies has continued to hold sway. Over the years, prominent policing scholars, including Professors Samuel Walker, Wayne LaFave, Eric Luna, and Debra Livingston, have all argued in favor of using administrative rulemaking procedures to guide officer discretion. . "[L]aw enforcement," wrote Professor Luna, "has much to learn from the successes and failures of modern administrative law." 8

In recent years, enthusiasm for police rulemaking — or a facsimile — has only grown. Professor Christopher Slobogin has argued forcefully in favor of subjecting "law enforcement [to] the rigors of administrative regulation." In Democratic Policing, Barry Friedman and I insisted that it was "fundamentally unacceptable for policing to remain aloof from the ordinary

\footnotetext{
${ }^{4}$ Goldstein, supra note 3, at 1126-28; KenNeth Culp Davis, Police DisCRetion 98-120 (1975).

5 NAT'L AdVISORY COMM'N ON CIVIL DISORDERS, REPORT 162-65 (1968); PRESIDENT'S COMM'N

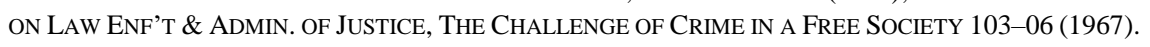

6 Am. Bar Ass'N Project on Standards For Criminal Justice, Standards Relating to the Urban Police Function 116-43 (1973); Am. LaW Inst., A Model Code of Pre-ArRaignment PROCEDURE (1975). State-level projects also took root in a variety of states. See, e.g., PROJECT ON LAW Enf't Policy \& Rulemaking, Ariz. State Univ. \& Police Found., Model Rules for law ENFORCEMENT: RELEASE OF ARREST AND CONVICTION RECORdS (1973); TEX. CRiminal Justice Council, Model Rules for law Enforcement Officers: A Manual on Police Discretion (1974); Fred A. Wileman, Univ. of Wis. Inst. Of Governmental AfFairs, Model Policy Manual FOR POLICE AGENCIES (1976).

7 See Wayne R. LaFave, Controlling Discretion by Administrative Regulations: The Use, Misuse, and Nonuse of Police Rules and Policies in Fourth Amendment Adjudication, 89 MicH. L. REV. 442, 449451 (1990) (arguing that courts should do more to encourage police rulemaking and highlighting the benefits of doing so); Debra Livingston, Police Discretion and the Quality of Life in Public Places: Courts, Communities, and the New Policing, 97 Colum. L. Rev. 551, 658-63 (1997) (suggesting rulemaking as one way to cabin discretion and enhance community-police reciprocity); Erik Luna, Principled Enforcement of Penal Codes, 4 BUFF. CRIM. L. REV. 515, 594-608 (2000) (arguing in favor of rulemaking to cabin enforcement discretion); Samuel Walker, Controlling the Cops: A Legislative Approach to Police Rulemaking, 63 U. DET. L. REV. 361, 382-91 (1986) (arguing for legislativelymandated police rulemaking). See generally Gregory Howard Williams, Police Rulemaking Revisited: Some New Thoughts on an Old Problem, 47 L. \& CONTEMP. PROBS. 123 (1984) (arguing that police have the authority to engage in rulemaking and should do so to enhance uniformity in arrest decisions).

${ }^{8}$ Luna, supra note 7, at 592.

${ }^{9}$ Christopher Slobogin, Panvasive Surveillance, Political Process Theory, and the Nondelegation Doctrine, 102 GEO. L.J. 1721, 1771 (2014); see also Christopher Slobogin, Policing as Administration, 165 U. PA. L. REV. 91, 134-40 (2016) (arguing that police must engage in notice-and-comment rulemaking when implementing suspicionless search and seizure regimes).
} 
processes of democratic governance"-by which we likewise meant the familiar processes of legislative authorization and public rulemaking used throughout the administrative state. ${ }^{10}$ Many others have argued in favor of giving "local communities ... a more meaningful voice in evaluating and checking local police policy" through rulemaking, informal consultation, or even local city council approval. ${ }^{11}$ Nationally, a number of prominent organizations have called for greater public involvement in police decisionmaking, as has (yet another) presidential commission. ${ }^{12} \mathrm{We}$ are, in short, in the midst of a rulemaking renaissance.

10 Barry Friedman \& Maria Ponomarenko, Democratic Policing, 90 N.Y.U. L. REV. 1827, 1827 (2015).

11 Eric J. Miller, Challenging Police Discretion, 58 How. L.J. 521, 525 (2015); see also ANDREW Guthrie Ferguson, The Rise of Big Data Policing: Surveillance, Race, and the Future of LAW ENFORCEMENT 188-201 (2017) (arguing for surveillance summits as one way to bring public accountability to police policymaking); Richard A. Bierschbach, Fragmentation and Democracy in the Constitutional Law of Punishment, 111 Nw. U. L. REv. 1437, 1453 (2017) (arguing in favor of "[s]ubjecting wholesale police, prosecutorial, and sentencing policies to some variant of a notice-andcomment process"); Richard A. Bierschbach \& Stephanos Bibas, Notice-and-Comment Sentencing, 97 Minn. L. Rev. 1, 36 (2012) (same); Catherine Crump, Surveillance Policy Making by Procurement, 91 WASH. L. REV. 1595, 1656 (2016) (arguing that police departments should get local approval before accepting surveillance technologies through federal grant programs); Sunita Patel, Toward Democratic Police Reform: A Vision for "Community Engagement" Provisions in DOJ Consent Decrees, 51 WAKE FOREST L. REV. 793, 816-17 (2016) (highlighting community engagement provisions in DOJ consent decrees as a means by which police agencies can be democratized); Kami Chavis Simmons, New Governance and the "New Paradigm" of Police Accountability: A Democratic Approach to Police Reform, 59 CATH. U. L. REv. 373, 379 (2010) (advocating for a "bottom-up approach" to police policymaking that allows for "stakeholder engagement and local experimentation"); Christopher Slobogin, Community Control Over Camera Surveillance: A Response to Bennett Capers's Crime, Surveillance, and Communities, 40 FORDHAM URB. L.J. 993, 997 (2013) (arguing for legislative authorization of police surveillance "by a truly representative body," such as a neighborhood council); Jonathan M. Smith, Closing the Gap Between What is Lawful and What is Right in Police Use of Force Jurisprudence by Making Police Departments More Democratic Institutions, 21 MICH. J. RACE \& L. 315, 336 (2016) (calling for democratization of policing, including the policy formulation process). There also has been a broader push to democratize criminal justice policymaking more generally. See, e.g., John Braithwaite, Criminal Justice That Revives Republican Democracy, 111 Nw. U. L. REv. 1507, 1519-22 (2017) (arguing for democratizing criminal justice through restorative justice); Joshua Kleinfeld, Manifesto of Democratic Criminal Justice, 111 Nw. U. L. REv. 1367, 1378 (2017) (advocating a range of reforms to "democratize criminal justice").

12 President's Task Force on 21st Century Policing, Final Report of the President's TASK ForCe ON 21St CENTURy POLICING 19 (2015); see also INT'L ASS'N OF CHIEFS OF POLICE, IACP NATIONAL Policy SUMmit ON COMMUNITY-POLICE RELATIONS: AdVANCING A CULTURE OF COHESION AND COMMUNITY TRUST 16 (2015) (urging agencies to pursue "true partnership" which involves "institutionalized inclusion of citizens in the business of the police department"); JUSTICE Collaboratory, Yale Law Sch., Principles of Procedurally Just Policing 14-15 (2018) ("When writing policies, departments should seek community input through one or more structured processes that provide community members with meaningful opportunities to be heard."); POLICING ProjeCt, N.Y.U. SCH. OF LAW, Statement OF PRinCIPLES On DemOCRATIC Policing (2017) (urging, in a statement signed on to by several major law enforcement and civil liberties organizations, that "policing practices should be guided by rules... [that] are formulated with input from the public"), 
And yet, there are serious reasons to doubt whether rulemaking - either along the lines of the federal model or the proposed alternatives - is in fact a viable strategy for governing the police. As often is true, the devil is in the details. But despite more than five decades of scholarship devoted to making the case for police rulemaking, there has been very little attention paid to how rulemaking would actually work in practice. A closer look makes clear that despite its intuitive appeal, administrative rulemaking is not a particularly apt solution to policing's various ills.

The reason for this is simple, if often overlooked: Although policing agencies are agencies, they are fundamentally different from the sorts of agencies in which rulemaking predominates. Elsewhere in government, notice-and-comment rulemaking is used primarily to ensure that agencies regulate us sensibly. ${ }^{13}$ Agencies like the Environmental Protection Agency (or the local board of public health) rely on rules to tell the public what to do. They use rules, for example, to set emissions standards or to instruct manufacturers on how to handle certain foods safely. ${ }^{14}$ The Administrative Procedure Act's (APA's) notice-and-comment requirements, in turn, require agencies to obtain public input before these sorts of outward facing (or "legislative") rules go into effect. ${ }^{15}$

Policing agencies do not-and may not-use rules in the same way. The police are not authorized to regulate the public through rules. ${ }^{16}$ When scholars argue in favor of police rulemaking, the sorts of rules they have in mind are rules that tell officers what they can and cannot do in enforcing the law. ${ }^{17}$ They are, in short, rules that policing agencies use to regulate themselves.

https://www.policingproject.org/s/Democratic-Policing-Principles-11_27_2017.pdf [https://perma.cc/2UX5-QSYP].

${ }^{13}$ Under the Administrative Procedure Act (APA), for example, agencies are only required to get public input on so-called legislative rules- that is, rules that tell the public what to do or alter the public's rights or obligations in some way. 5 U.S.C. $\$ 553(\mathrm{~b})(3)(\mathrm{A})$ (2012) (exempting "interpretative rules, general statements of policy, or rules of agency organization, procedure, or practice" from rulemaking requirements).

14 See, e.g., 40 C.F.R. $\$ 86.1811-04$ (2005) (setting emission standards for light-duty vehicles, lightduty trucks, and medium-duty passenger vehicles); 9 C.F.R. $\$ 416.4$ (1999) ("All food-contact surfaces ... must be cleaned and sanitized as frequently as necessary to prevent the creation of insanitary conditions and the adulteration of product.").

155 U.S.C. $\$ 553$ (b)-(c) (defining the rulemaking process). The APA's notice-and-comment procedure requires "informing the public of [the agency's] proposed rules, soliciting comment on those proposals, and responding in a reasoned way to significant objections to the agency's proposed course of action.” M. Elizabeth Magill, Agency Choice of Policymaking Form, 71 U. CHI. L. REV. 1383, 1390 (2004).

16 Friedman \& Ponomarenko, supra note 10, at 1857.

17 See infra note 57 (describing the sorts of practices that scholars have argued should be regulated through public rulemaking). 
As this Article explains, the difference between the legislative rules that typically are subject to administrative rulemaking requirements and the internal rules that policing agencies adopt has several implications for the viability of APA-style rulemaking in the policing space. First, policing agencies have far fewer incentives than traditional administrative agencies to adopt rules. ${ }^{18}$ And without rules, there is nothing on which the public can comment. Although legislatures could require policing agencies to issue rules, these sorts of requirements would be difficult both to articulate and to enforce, particularly when it comes to policing practices that are of greatest concern. ${ }^{19}$ It also is much harder in the policing context to specify when policing agencies would need to obtain public input on the rules they do in fact have. ${ }^{20}$ Finally, because police rules regulate internal systems - the workings of which commonly are hidden from public view-it often is more difficult for the public to provide input on the substance of those rules. ${ }^{21}$

This last point has implications not only for the feasibility of APA-style rulemaking requirements but also for the broader push to "democratize" policing by creating opportunities for the public to participate in police decisionmaking. The tendency across much of this literature has been to reduce police policymaking to a series of "referendum-style" questions, such as whether to get body-worn cameras, or whether officers should be required to "deescalate" potentially violent encounters. ${ }^{22}$ Framed in this manner, it is easy to imagine members of the public having strong views and those views potentially influencing what the police do. In practice, however, many of the problems that people have identified with policing are the product of elaborate systems, comprised of many overlapping policies and practices. ${ }^{23}$ It simply is not realistic to think that the public can meaningfully address systemic shortfalls by providing periodic comment on some of the more salient aspects of police department rules.

For all of these reasons, this Article argues that to improve policing outcomes, scholars and reformers should look beyond rulemaking and consider other important features of agency design. ${ }^{24}$ Within administrative law, a great deal of work has been done to assess the degree to which various institutional design choices can facilitate or impede agency function and

\footnotetext{
18 See infra Section II.A.

19 See infra Section II.B.

20 See infra Section II.C.

21 See infra Section II.D.

22 See infra notes 190-194 and accompanying text.

23 See infra note 194 and accompanying text.

24 See infra Part III.
} 
political control. ${ }^{25}$ Although a small number of scholars have begun to apply some of these insights to other criminal justice agencies-including prosecutors' offices, sentencing commissions, and national intelligence agencies - very little work has been done around policing, which presents a different set of regulatory challenges. ${ }^{26}$

This Article begins to fill this gap. Part I briefly describes some of the problems with policing that have drawn public scrutiny-all of which policing scholars have argued could be improved through administrative rulemaking. It also summarizes some of the conventional arguments that others have made about the limits of rulemaking, which, although important, have done little to undermine the core case in favor of extending APA-style rulemaking to the police. Part II makes clear that the problems with rulemaking run quite a bit deeper than scholars have recognized. It argues that although some areas of policing, particularly the use of surveillance technologies, fit comfortably within the rulemaking paradigm, others, like the use of force or the exercise of enforcement discretion, largely do not. Part III suggests that a more promising alternative to rulemaking is to create "regulatory intermediaries" - entities within government, such as commissions or inspectors general, which can stand in for the public and help govern the police. It also points out that given some of the obstacles to governing policing locally, it may be worth considering to what extent police decisions should be made locally at all.

\footnotetext{
25 Institutional design refers to how an organization is structured to operate, and these deliberate choices can include extent of authority, leadership model, and relative placement in a bureaucratic reporting structure. See, e.g., Kenneth A. Bamberger \& Deirdre K. Mulligan, Privacy Decisionmaking in Administrative Agencies, 75 U. CHI. L. REV. 75 (2008) (exploring the effect of agency structure on the degree to which agencies incorporate privacy concerns into their decisionmaking); Rachel E. Barkow, Overseeing Agency Enforcement, 84 GEO. WASH. L. REV. 1129 (2016) (analyzing the ways in which agency design can impede or promote public oversight of agency enforcement discretion); Christopher R. Berry \& Jacob E. Gersen, Essay, Agency Design and Political Control, 126 YALE L.J. 1002 (2017) (assessing the effect of budgeting decisions on agency design); Patrick M. Corrigan \& Richard L. Revesz, The Genesis of Independent Agencies, 92 N.Y.U. L. REV. 637 (2017) (analyzing what factors make agencies more likely to be independent); Jacob E. Gersen, Administrative Law Goes to Wall Street: The New Administrative Process, 65 ADMIN. L. REV. 689 (2013) (discussing the use of various agency design and oversight structures in shaping recent financial regulatory reforms); Neal Kumar Katyal, Internal Separation of Powers: Checking Today's Most Dangerous Branch From Within, Essay, 115 YALE L.J. 2314 (2006) (proposing reforms of internal separation of powers within the executive branch); Gillian E. Metzger, The Interdependent Relationship Between Internal and External Separation of Powers, 59 EMORY L.J. 423 (2009) (same).

26 See Rachel E. Barkow, Administering Crime, 52 UCLA L. REV. 715 (2005) (sentencing commissions); Rachel E. Barkow, Institutional Design and the Policing of Prosecutors: Lessons from Administrative Law, 61 STAN. L. REV. 869 (2009) (prosecutors' offices); Samuel J. Rascoff, Domesticating Intelligence, 83 S. CAL. L. REV. 575 (2010) (domestic intelligence programs); Daphna Renan, The Fourth Amendment as Administrative Governance, 68 STAN. L. REV. 1039 (2016) (programmatic surveillance); Margo Schlanger, Offices of Goodness: Influence Without Authority in Federal Agencies, 36 CARdozo L. REV. 53 (2014) (Offices of Goodness).
} 
To be clear at the outset, the goal of this Article is not to question the utility of encouraging policing agencies to open up their decisionmaking processes to greater public scrutiny. Given the lack of transparency around policing, and the substantial legitimacy deficit in many communities, efforts to make policing more open and collaborative are a step in the right direction. The question this Article tackles is whether public rulemaking alone is a viable strategy for governing policing - that is, for getting policing agencies to do things that they might not otherwise be inclined to do. At the end of the day, it argues that law enforcement may indeed have "much to learn from the successes and failures of modern administrative law" 27 - but that the lessons lie beyond the notice-and-comment provisions of the APA.

\section{RULEMAKING'S ALLURE}

Over the years, commentators and scholars have pointed to a variety of problems with policing, from excessive force to discriminatory enforcement to the persistent creep of the surveillance state. And they have pointed to administrative rulemaking as a possible solution. This Part begins by briefly describing some of the problems with policing that have drawn the most attention. It then explains rulemaking's enduring appeal. It concludes by summarizing the conventional objections that others have raised about the limits of police rulemaking, none of which really address the core of why APA-style rulemaking is not a particularly apt solution to policing's ills.

\section{A. The Problems with Policing}

By far the most salient issue around policing has been the use of excessive force-particularly in communities of color. Complaints about police violence have plagued policing for decades. ${ }^{28}$ Many can recall the high-profile incidents that have occasionally brought the problem to the fore-from the beating of Rodney King to the more recent killings of Michael Brown, Eric Garner, and Tamir Rice. ${ }^{29}$ As Obama-era Justice Department investigations in cities like Baltimore, Chicago, Cleveland, Miami, Newark, New Orleans, and Seattle made clear, these events are not isolated incidents. ${ }^{30}$ In far too many jurisdictions, officers are too quick to

\footnotetext{
27 Luna, supra note 7 , at 592.

28 See, e.g., James Baldwin, A Report from Occupied Territory, NATION (July 11, 1966) (describing routine police abuses in 1960s Harlem).

29 Smith, supra note 11, at 315, 334-39.

${ }^{30}$ Each of these reports found that the city police department "engage[d] in a pattern or practice of ... using excessive force.” U.S. DeP'T OF Justice, Civil Rights Div., InVeStigation of the BAltimore City Police DePARTMENT 3 (2016) [hereinafter BALTiMORE DOJ REPORT]; U.S. DEP’T OF Justice, Civil Rights Div. \& U.S. ATt'Y's OfFice, N. Dist. Of ILl., INVESTIGATION OF THE CHICAGO Police Department 11 (2017) [hereinafter Chicago DOJ Report]; U.S. DeP’T of Justice, Civil
} 
pull the trigger in circumstances that do not warrant the use of deadly force. ${ }^{31}$ And they too often resort to force as punishment for talking back or attempting to flee..$^{32}$ Equally troubling is the fact that officers rarely are held accountable for doing so. The Justice Department's various investigations confirmed what communities long suspected: that use of force incidents often go unreported, and that when they are, investigations are stacked heavily in favor of the police..$^{33}$

Another recurring complaint has been around the use of stop and frisk and other intrusive street-level enforcement tactics. Bound up in the critiques of stop and frisk are four distinct complaints: that officers make far too many stops; that stops often are plainly unconstitutional; that people of color are disproportionately likely to be stopped; and that stops sometimes are conducted in a harsh and disrespectful manner. ${ }^{34}$ In New York City, for example, the NYPD conducted more than 4.4 million stops between 2004

RighTS DiV., INVESTIGATION OF THE CLEVELAND Division OF POLICE 3 (2014) [hereinafter CLEVELAND DOJ REPORT]; Letter from Thomas E. Perez, Assistant Att'y Gen., to the Hon. Tomas P. Regalado, Mayor, City of Miami \& Chief Manuel Orosa, City of Miami Police Dep't, Investigation of the City of Miami Police Department (July 9, 2013) [hereinafter MiAmi DOJ REPORT]; U.S. DEP’T OF JUSTICE, CiVIL Rights Div. \& U.S. ATt'y's OfFice, Dist. OF N.J., InVestigation of the Newark Police DEPARTMENT 22 (2014) [hereinafter NEWARK DOJ REPORT]; U.S. DEP'T OF JUSTICE, CIVIL RIGHTS Div., InVESTIGATION OF THE NEW ORLEANS Police DEPARTMENT 1 (2011) [hereinafter NeW ORLEANS DOJ REPORT]; U.S. DEP'T OF JuSTICE, CIVIL RightS Div. \& U.S. ATT'Y'S OFFICE, W. DisT. OF WASH., InVESTIGATION OF THE SEATtLE POLICE DEPARTMENT 3 (2011) [hereinafter SEATtLE DOJ REPORT].

31 See, e.g., ChICAGO DOJ REPORT, supra note 30, at 25-26; Cleveland DOJ REPORT, supra note 30, at 14-18; NEW ORLEANS DOJ REPORT, supra note 30, at 8-9.

32 See, e.g., BALTIMORE DOJ REPORT, supra note 30, at 88 (noting the use of baton strikes by BPD officers as punishment for failure to heed an order); CHICAGO DOJ REPORT, supra note 30, at 33-34 (highlighting CPD use of "retaliatory force" against individuals who dispute the lawfulness of their police stops); NEWARK DOJ REPORT, supra note 30, at 24 (noting that many cases where NPD officers struck suspects with their fists appeared to be retaliatory); SEATTLE DOJ REPORT, supra note 30, at 14 (finding that SPD engages in a pattern or practice of using unreasonable force against individuals who "talk back").

33 See, e.g., BALTIMORE DOJ REPORT, supra note 30, at 10 (noting that BPD conducts minimal or no investigation of reported officer misconduct); CLEVELAND DOJ REPORT, supra note 30, at 5 ("[DOJ] reviewed supervisory investigations of [CDP] officers' use of force that appear to be designed from the outset to justify the officers' actions."); MIAMI DOJ REPORT, supra note 30, at 9 (finding that MPD "fail[s] to timely and thoroughly investigate officer-involved shootings"); NEW ORLEANS DOJ REPORT, supra note 30, at 14 (finding significant underreporting of force by NOPD officers).

34 See Ctr. For Constitutional Rights, Stop And Frisk: The Human Impact 1 (2012), https://ccrjustice.org/sites/default/files/attach/2015/08/the-human-impact-report.pdf [https://perma.cc/TB8A-J8MG] (exploring these issues in interviews with New Yorkers who were stopped and frisked and experienced "illegal profiling, improper arrests, inappropriate touching, sexual harassment, humiliation and violence at the hands of police officers"); Floyd v. City of New York, 959 F. Supp. 2d 540 (S.D.N.Y. 2013) (addressing constitutionality and disproportionate racial impact of stops); Aziz Z. Huq, The Consequences of Disparate Policing: Evaluating Stop and Frisk as a Modality of Urban Policing, 101 MinN. L. REV. 2397, 2398 (2017) (noting the frequency of stops in some neighborhoods). 
and 2012. ${ }^{35}$ The vast majority of those stopped were black or Hispanic. ${ }^{36}$ And the vast majority were innocent of any wrongdoing. ${ }^{37}$ Yet they were stopped, questioned, and often searched. ${ }^{38}$ In an unknown (and unknowable) number of cases, they were threatened with force, or subjected to racial slurs, or otherwise treated with contempt. ${ }^{39}$ "[F] or many urban residents," writes Professor Aziz Huq, these encounters "likely became the modal form of police-citizen contact." ${ }^{40}$ The costs of these encounters have been welldocumented, and are undoubtedly substantial. ${ }^{41}$

Still others, particularly in recent years, have focused attention on the unrelenting creep of the surveillance state. Policing agencies have at their disposal a growing array of surveillance tools - including drones, CCTV cameras, license plate readers, and social media monitoring tools-with still more pervasive surveillance capabilities, like real-time facial recognition, possibly right around the corner. ${ }^{42}$ For some, the concern has been about the

35 Floyd v. City of New York, 959 F. Supp. 2d 540, 556 (S.D.N.Y. 2013). In some Baltimore neighborhoods, officers recorded nearly 1.5 stops per resident per year which, given systemic underreporting, meant that they likely conducted a great deal more. BALTIMORE DOJ REPORT, supra note 30 , at 26 .

36 Floyd, 959 F. Supp. 2d at 556.

${ }^{37}$ In New York, fewer than $12 \%$ of stops resulted in a summons or an arrest, and fewer than $0.2 \%$ produced a firearm. N.Y. Civil Liberties Union, StOP \& Frisk DuRing THE BloOMberg ADMINISTRATION (2002-2013) 14-16 (2014).

38 In New York, officers frisked over 50\% of those stopped. Id. at 7. The term "frisk" is a poor euphemism for the intrusion that a pat down entails. See DAVID K. SHIPLER, THE RIGHTS OF THE PEOPLE: HOW OUR SEARCH FOR SAFETY INVADES OUR LIBERTIES 40 (2011) (quoting a Washington, D.C. police instructor telling recruits to "Put your fingers between the belt and the waistband. He may say, 'I'm sensitive down there.' Well, aren't we all.").

39 See, e.g., Jennifer Fratello Et Al., Vera InSt. of Justice, Coming OF AgE With STOP AND FRISK: EXPERIENCES, PERCEPTIONS, AND PUBLIC SAFETY IMPLICATIONS 30 (2013) (nearly half of the respondents reported that they were threatened or experienced force); Ross Tuttle \& Erin Schneider, Stopped-and-Frisked: 'For Being a F*cking Mutt', NATION (Oct. 8, 2012), https://www.thenation.com /article/stopped-and-frisked-being-fking-mutt-video [https://perma.cc/DJ3F-WW34] (describing a recording showing an officer using a racial slur in an encounter with a minor).

40 Huq, supra note 34, at 2398.

41 See id. at 2429-40 (arguing that there are eight distinctive "ecological and dynamic costs" of stop and frisk); Amanda Geller et al., Aggressive Policing and the Mental Health of Young Urban Men, 104 AM. J. PUB. HEALTH 2321, 2323-24 (2014) (finding that individuals stopped and frisked by police report more symptoms of anxiety and trauma); Rachel A. Harmon, Federal Programs and the Real Costs of Policing, 90 N.Y.U. L. REV. 870, 901-04 (2015).

42 See, e.g., FERGUSON, supra note 11, at 86-90 (describing the various technologies and data sources that agencies have at their disposal); Cynthia Lum et al., The Rapid Diffusion of License Plate Readers in U.S. Law Enforcement Agencies, 42 Policing: INT'L J. 376, 386 (2019) (estimating that between 66\% and $73 \%$ of agencies with 100 officers or more would have access to ALPRs by 2016); Conor Friedersdorf, The Surveillance City of Camden, New Jersey, ATLANTIC (Dec. 12, 2013), https://www.theatlantic.com/national/archive/2013/12/the-surveillance-city-of-camden-new-

jersey/282286 [https://perma.cc/8NBS-TF7H] (discussing the Camden police "force multipliers," which include 121 sidewalk cameras, 35 microphones to detect the location of gunfire, a SkyPatrol crane that 
sheer ubiquity of surveillance and the threat that it poses to individual privacy and free expression and association..$^{43}$ For others, the fear is that these new technologies will further exacerbate existing racial disparities throughout the criminal justice system. ${ }^{44} \mathrm{~A}$ third risk, related to the other two, is that policing technologies can easily be abused. ${ }^{45}$ Agencies can use the technologies intentionally to target individuals on the basis of religion, political affiliation, or race. ${ }^{46}$ Individual officers can misuse the tools for private gain, for example, by using a license plate database to track a wayward spouse. ${ }^{47}$

Finally, at least since the 1960 s, one of the predominant concerns with policing - if not the central concern - has been with police discretion..$^{48}$ It often is said that policing is "shot through with discretion." 49 Officers decide where to patrol and whom to stop, whether to issue a warning for a broken taillight or write a ticket, and whether to throw a joint in the gutter, issue a summons, or make an arrest. Commanders decide whether to prioritize the rash of commercial burglaries or to try to do something about the dealers on the corner.

\footnotetext{
can monitor six square blocks, and a fleet of cruisers equipped with ALPRs); Timothy Williams, Can 30,000 Cameras Help Solve Chicago's Crime Problem?, N.Y. TIMES (May 26, 2018), https:// www.nytimes.com/2018/05/26/us/chicago-police-surveillance.html [https://perma.cc/FY9G-BP6X]. In 2018, several body camera manufacturers announced plans to outfit cameras with real-time facial recognition technology, which could scan people's faces as they pass by and alert officers if there is a potential match to a suspect database or heat list. Shibani Mahtani \& Zusha Elinson, Artificial Intelligence Could Soon Enhance Real-Time Police Surveillance, WALL ST. J. (Apr. 3, 2018), https://www.wsj.com/articles/artificial-intelligence-could-soon-enhance-real-time-police-surveillance1522761813 [https://perma.cc/NR3R-PUC2]. Some jurisdictions already use facial recognition technology to scan faces at entry points to major sporting events and have explored adding real-time facial recognition capability to CCTV cameras as well. Clare GARVIĘ ET AL., GEO. LAW, CTR. ON PRIVACY \& Tech., Perpetual Line-Up: Unregulated Police Face Recognition in America (2016), https://www.perpetuallineup.org [https://perma.cc/CBA6-AMKQ].

${ }^{43}$ See, e.g., Crump, supra note 11, at 1644; Neil M. Richards, The Dangers of Surveillance, 126 HARV. L. REV. 1934, 1935 (2013); Katherine J. Strandburg, Freedom of Association in a Networked World: First Amendment Regulation of Relational Surveillance, 49 B.C. L. REV. 741, 748 (2008).

44 Predictive policing algorithms that are trained on criminal justice data-which itself reflects decades of biased enforcement - could focus still more police attention on communities of color by marking certain individuals or neighborhoods as more prone to criminality than they in fact are. Andrew Guthrie Ferguson, Policing Predictive Policing, 94 WASH. U. L. REV. 1109, 1146-50 (2017).

45 Crump, supra note 11, at 1644-45.

${ }^{46} \mathrm{Id}$.

47 Id.

48 See generally DAVIS, supra note 4; LaFave, supra note 7; Livingston, supra note 7; Erik Luna, Transparent Policing, 85 IowA L. REv. 1107 (2000) (discussing concerns with discretion in the enforcement of criminal law); Miller, supra note 11, at 525.

49 See, e.g., David D. Cole, Formalism, Realism, and the War on Drugs, 35 SUFFOLK U. L. REV. 241, 245 (2001); Friedman \& Ponomarenko, supra note 10, at 1860.
} 
The problem, of course, is not so much with discretion itself, but with how that discretion is used. Too often, the failure to sufficiently cabin discretion has resulted in both over- and under-enforcement, typically at the expense of racial minorities and other marginalized groups..$^{50}$ The statistics are all too familiar. African-Americans are nearly four times more likely to be arrested for marijuana possession than are whites, despite similar rates of use. ${ }^{51}$ Certain crimes like loitering or riding a bicycle on the sidewalk are far more likely to be enforced in poor black neighborhoods than in affluent white ones. ${ }^{52}$ At the same time, residents in low-income, minority neighborhoods have complained for decades about "unsolved homicides, permitted open-air drug markets, slow or nonexistent 911 responses, and tolerance of pervasive, low levels of violence." ${ }^{53}$ Often, it is the very same residents who report feeling both underprotected and overpoliced. ${ }^{54}$

Together, these four sets of problems - excessive force, stop and frisk, surveillance, and discretion-are emblematic of the different sorts of regulatory problems that policing presents. And for this reason, they are used throughout this Article to illustrate the inherent challenges in adapting APAstyle rulemaking to the policing space. In reality of course, there are any number of other practices that one could discuss. The events in Ferguson following the killing of Michael Brown drew attention to two other troubling facets of policing: policing for profit, as well as the militarization of local police. ${ }^{55}$ Many also have criticized the lack of controls around the use of informants, particularly juveniles, who often are needlessly put in harm's

${ }^{50}$ On the broader concerns with enforcement discretion and the potential it leaves for arbitrary or uneven enforcement, see DAVIS, supra note 4, at 98-120.

51 ACLU, THE WAR ON MARIJUANA IN BLACK AND White 12 (2013).

52 Between 2008 and 2011, New York City police issued more than two thousand summonses for riding a bicycle on a sidewalk in the predominantly black neighborhood of Bedford-Stuyvesant, but just eight such summonses in predominantly white (and affluent) Park Slope. Tobi Haslett, Broken Windows Comes to Park Slope, NEw YORKER (Nov. 10, 2015), https://www.newyorker.com/news/newsdesk/broken-windows-comes-to-park-slope [https://perma.cc/5ZNE-7GXQ].

53 Alexandra Natapoff, Underenforcement, 75 FORDHAM L. REV. 1715, 1723 (2006).

54 See Randall Kennedy, Race, Crime, And the Law 19 (1997); Monica C. Bell, Police Reform and the Dismantling of Legal Estrangement, 126 YALE L.J. 2054, 2069 (2017); Natapoff, supra note 53, at 1719 ("Over- and underenforcement are twin symptoms of a deeper democratic weakness of the criminal [justice] system: its non-responsiveness to the needs of the poor, racial minorities, and the otherwise politically vulnerable.").

55 On militarization, see Shirley Li, The Evolution of Police Militarization in Ferguson and Beyond, ATLANTIC (Aug. 15, 2014), https://www.theatlantic.com/national/archive/2014/08/the-evolution-ofpolice-militarization-in-ferguson-and-beyond/376107/ [https://perma.cc/U5FR-MCD3]; on policing for profit, see, for example, Jeffrey Fagan \& Elliot Ash, New Policing, New Segregation: From Ferguson to New York, 106 GEO. L.J. ONLINE 33 (2014). 
way. ${ }^{56}$ Policing, in short, presents a variety of problems that cry out for careful regulation. The question that this Article tackles is whether rulemaking is the right strategy for bringing them under control.

\section{B. The Enduring Appeal of Administrative Rulemaking}

Over the years, scholars have argued that many of the problems with policing could be addressed through administrative rulemaking - that is, by requiring policing agencies to articulate key policing decisions through written rules, with some opportunity for public input and debate. ${ }^{57}$ Many others have argued more broadly in favor of "democratizing" police decisionmaking around these practices. ${ }^{58}$ The theory behind these proposals is both intuitive and compelling.

As rulemaking proponents point out, policing agencies operate very differently from other agencies of government. Federal, state, and local agencies issue thousands of pages of regulations each year - on matters large and small. And they routinely consult with the public in developing policies and rules on everything from nuclear regulation to the placement of turnstiles at a local subway station. Indeed, under the Federal APA and its state and local analogues, agencies are required to get public input and to respond to the substance of any comments received before agency rules may go into effect. $^{59}$

Police departments, by contrast, often lack policies on critical aspects of policing - such as the exercise of enforcement discretion. And to the

\footnotetext{
${ }^{56}$ See AlEXANDRA NATAPOFF, SNITCHING: CRIMINAL Informants AND THE EROSION OF AMERICAN Justice (2009); Sarah Stillman, The Throwaways, New YorkeR (Aug. 27, 2012), http://www.newyorker.com/magazine/2012/09/03/the-throwaways [https://perma.cc/BKZ8-LTV2].

57 A number of scholars, including Professors Anthony Amsterdam, Herman Goldstein, Eric Miller, and Samuel Walker have called for police to use something akin to notice-and-comment rulemaking in developing policies around the use of force, as well as investigative tactics like stop and frisk. See Amsterdam, supra note 3, at 414-28; Goldstein, supra note 3, at 1126-28; Miller, supra note 11, at 54548; Walker, supra note 7, at 370-74. Professors Catherine Crump, Christopher Slobogin, and others have argued in favor of rulemaking to govern police use of surveillance technologies and other "panvasive" investigative tactics. See Crump, supra note 11, at 1658-62; Slobogin, supra note 11, at 996-97; Slobogin, Policing as Administration, supra note 9, at 137-40. Professors Kenneth Culp Davis, Debra Livingston, and Erik Luna all have pointed to rulemaking as a way to cabin enforcement discretion and to ensure that police exercise their discretion in a manner that reflects community views. See DAVIS, supra note 1, at 96; Livingston, supra note 7, at 658-63; Luna, supra note 7, at 603-05. And of course, Professor Barry Friedman and I argued that the public should have an opportunity to weigh in on all police policies that affect them-and pointed to notice-and-comment rulemaking as one model for how this might occur. Friedman \& Ponomarenko, supra note 10, at 1843-48.

58 See Patel, supra note 11, at 871-77; Simmons, supra note 11, at 408-10; Smith, supra note 11, at 336; see also supra note 11 and accompanying text (listing other scholars who have advocated for expanded opportunities for public input in police decisionmaking processes).

59 As discussed in Section II.A, infra, these requirements only apply to "legislative" rules. See infra notes $174-176$ and accompanying text.
} 
extent that there are department policies in place, they often are shielded from public view. ${ }^{60}$ Even when they are public, there is almost never any opportunity for the public to comment on the policies before they go into effect. ${ }^{61}$

Yet, as the discussion above makes clear, policing agencies routinely make crucial policy determinations that can (and do) quite literally involve matters of life and death. The idea that these decisions should be insulated from public scrutiny - or worse still, made on a case-by-case basis by individual officers without the benefit of formal guidance-is inconsistent with fundamental democratic norms. ${ }^{62}$ As Professor Slobogin put it, a "regime that requires the relevant agency to submit to administrative law constraints" when adopting rules concerning "workplace ergonomics," but "not when police want to require citizens to submit to ... surveillance, is seriously askew." 63

The connection between the lack of administrative processes around policing and the various policy shortfalls discussed above is readily apparent. One of the core goals of administrative rulemaking is to improve the quality of agency deliberations, and in doing so, to make policies better. When it comes to policing, particularly in the troubled departments that have drawn Justice Department scrutiny, there is no shortage of policy changes that could be made to improve outcomes at least to some degree. Justice Department consent decrees devote dozens of pages to specific policy changes that need to be made. In Baltimore, for example, the Justice Department found that the department's use of force policies were "scattered across multiple documents" and were "missing critical elements." ${ }_{44}$ And in Newark-where the Justice Department found that a staggering seventy-five percent of documented stops lacked reasonable suspicion-the department's stop policy incorrectly implied that presence in a "high crime area" alone may be sufficient to justify a stop. ${ }^{65}$ Had these agencies subjected their policies to

\footnotetext{
${ }^{60}$ Friedman \& Ponomarenko, supra note 10, at 1845-46.

${ }^{61} I d$.

62 See, e.g., Friedman \& Ponomarenko, supra note 10, at 1827 (arguing that "it is fundamentally unacceptable for policing to remain aloof from the ordinary processes of democratic governance"); Igleburger \& Schubert, supra note 3, at 309 (arguing that the public "should determine police enforcement policy in a democratic society"); Miller, supra note 11, at 536-45 (arguing that police policymaking that is insulated from the community is inconsistent with republican norms); David Alan Sklansky, Police and Democracy, 103 Mich. L. REV. 1699, 1819 (2005) (noting that police "often seem to operate outside the normal processes of local government").

63 Slobogin, Policing as Administration, supra note 9, at 133-34.

${ }^{64}$ BALTIMORE DOJ REPORT, supra note 30, at 98.

65 NEWARK DOJ REPORT, supra note 30, at 9-10 (noting that the department's policies include "[h]igh crime areas and the type of activity that takes place there" and "[p]roximity to scene of a crime" as "reasonable suspicious factors to stop a person").
} 
notice-and-comment rulemaking, perhaps some of these changes would already have been in place.

Public rulemaking also could help bring policies more into line with what community members expect. As Professor Goldstein argued in the 1960s, for example, police department policies around stop and frisk (known at the time as "field interrogation") as well as the enforcement of quality of life offenses would likely look quite different if departments were required to put their policies in writing and to consult with members of affected communities in their adoption. ${ }^{66}$ Professor Davis echoed similar themes, noting that many enforcement practices were "illegal or of doubtful legality" and would never have been sanctioned had police officials been required to adopt them through public rules. ${ }^{67}$ More recently, scholars have pointed to a number of examples of police department policies - on issues ranging from the use of surveillance technology to racial profiling — changing in response to greater public scrutiny and debate. ${ }^{68}$ And it is easy to see why: acting on his own, a police chief may jump at the chance to get the shiny new surveillance tool. If required to justify its use to the public, however, the chief may come to see that its vague benefits simply do not outweigh the steep privacy costs.

The core insight behind all of these arguments is that the problem of policing is, fundamentally, a problem of governance. By insulating policing agencies from the ordinary processes of administrative government, we have essentially left policing agencies to regulate themselves, with predictably troubling effects.

\section{The Conventional Case Against Police Rulemaking}

No one has argued, of course, that police rulemaking would be a panacea - or that it would easily be accomplished. Indeed, rulemaking proponents themselves have pointed to a variety of obstacles that their proposals would face. But if anything, these obstacles have only served to strengthen their resolve. Specifically, they and others have raised three important objections: the inherent limits of rules, the undemocratic character of administrative rulemaking, and the resource constraints that policing agencies face. But as this Section makes clear, there are fairly obvious

\footnotetext{
66 Goldstein, supra note 3, at 1140. The phrase "quality of life offenses" is used to describe a variety of low-level offenses, including loitering, littering, excessive noise, and public intoxication.

67 Kenneth Culp Davis, An Approach to Legal Control of the Police, 52 TEX. L. REV. 703, 703-04, 716-17 (1974).

68 See Crump, supra note 11, at 1604-28 (describing public backlash after residents became aware of surveillance practices in both Seattle and Oakland); Friedman \& Ponomarenko, supra note 10, at 1853 (describing similar backlash in Seattle and elsewhere).
} 
rejoinders to each. As a result, proponents have been able to argue that although rulemaking would be difficult to implement, the case in its favor nevertheless is fundamentally sound.

\section{The Difficulty of Writing and Enforcing Rules for the Police}

A common critique of police rulemaking has focused on the limitations of rules themselves. The argument is that rules will be quite difficult to write for certain areas of policing. When it comes to discretionary enforcement decisions, for example, it may not always be possible to construct a rule that captures the nuance of any given situation that an officer may face. ${ }^{69}$ Although agencies can provide guidance to officers on deciding when to issue a warning or make an arrest, many of the factors that legitimately could inform that decision - such as the degree to which a person is being disruptive to others or the likelihood that a warning will deter future conduct - are difficult to reduce to hard and fast rules. ${ }^{70}$

A related objection is that published rules and guidelines may not always be desirable. Professor Rachel Barkow points to two sets of concerns. ${ }^{71}$ First, although enforcement guidelines promote transparency and regularity, these gains may come at the expense of deterrence, particularly when guidelines are used to announce that certain laws will not be prioritized or will simply go unenforced. ${ }^{72}$ Agencies, writes Professor Barkow, may want "to deter conduct across a range of cases even if [their] limited resources may not make those cases a priority." ${ }^{\prime 73}$ A second concern is that given the politics around crime and criminal justice, making enforcement policies more transparent may result in policies that on the whole are harsher than what the agency might otherwise be inclined to pursue. ${ }^{74}$

Finally, it often is difficult to ensure that the rules will in fact be followed. Much has been written about police as the quintessential "streetlevel bureaucrats" who exercise vast stores of discretion, much of which is largely invisible to supervisors. ${ }^{75}$ Although certain enforcement decisions, like citations and arrests, generate a paper trail, many of the decisions that officers make do not. Unless an officer reports an encounter or a member of

\footnotetext{
${ }^{69}$ See Livingston, supra note 7, at 662-63.

70 See DAvis, supra note 4, at 151. Professor Debra Livingston also points out that if agencies adopt overly rigid rules, they risk having the rules ignored. Livingston, supra note 7, at 662-63.

${ }^{71}$ See Barkow, supra note 25, at 1154-59.

${ }^{72} I d$. at 1158. In certain contexts, of course, this may not matter, or may in fact be the goal. The Obama administration's immigration enforcement guidelines, for example, were designed to help undocumented immigrants feel more secure. $I d$.

$73 \mathrm{Id}$.

${ }^{74} I d$. (raising this concern in the context of prosecutors).

75 Michael Lipsky, Street-Level Bureaucracy: Dilemmas of the Individual in Public SERVICES 3 (30th Anniversary ed. rev. 2010); see also Livingston, supra note 7, at 662.
} 
the public lodges a complaint, a supervisor may have no way of knowing whether an officer approached a person on the street, conducted a stop or a frisk, told a group of young people to "move along," ordered a panhandler off a bus stop, treated someone abrasively, or used excessive force.

The problem is exacerbated by the fact that noncompliance sometimes has been tolerated or even encouraged, either by mid-level supervisors or department command. Supervisors have been known to accept deficient reports, ignore serious allegations of misconduct, and even encourage officers to violate department rules. ${ }^{76}$ And they may be particularly reluctant to enforce policies that they perceive to have been foisted on the department by outsiders. ${ }^{77}$ This last point is particularly troubling if the goal of rulemaking is to push policing policy in directions a department would not adopt on its own. Unless department supervisors buy in to the proposed policies (or are incentivized to do so through external monitoring or political controls), even the most stringent rules may only accomplish so much.

As rulemaking proponents point out, however, these objectionsalthough important - are at best a cautionary tale about the outer limits of rules. The reality is that at present, policing agencies are nowhere close to the point at which one might start to wonder whether there cannot be more and better rules to write that could improve things at least to some degree. In many departments, for example, use of force policies simply instruct officers to use whatever force is "reasonable" to address the situation at issue. ${ }^{78}$ There is no question that these departments can and must provide more guidance to their officers about when force may be used. Where rules are not feasible, agencies still can develop guidelines, strategic plans, and performance benchmarks to guide agency action and make policy choices more transparent to the public. ${ }^{79}$ Although it may be difficult to ensure perfect

\footnotetext{
76 See, e.g., BALTIMORE DOJ REPORT, supra note 30, at 29 (describing multiple Baltimore police sergeants who were observed encouraging patrol officers to make illegal stops); CLEvELAND DOJ REPORT, supra note 30, at 6,11-12 (finding that police supervisors "routinely approved ... inadequate reports without seeking additional information from the officers"); NEWARK DOJ REPORT, supra note 30, at 25-27 (documenting Newark Police Department's inadequate reporting and review systems).

77 See, e.g., CHICAGO DOJ REPORT, supra note 30, at 102 (describing CPD's haphazard effort to roll out a new pedestrian stop reporting policy, which was mandated by a settlement with the ACLU).

78 See Brandon Garrett \& Seth Stoughton, A Tactical Fourth Amendment, 103 VA. L. REV. 211, 278 (2017) (noting that many use of force policies "say very little at all beyond a constitutional floor of 'reasonableness"').

79 Recruitment and training, for example, are two areas that would seem to be difficult to reduce to rules. And yet, as part of the consent decree process in Cleveland, the Division of Police has prepared detailed staffing and recruitment plans, which establish minimum staffing levels for various units, and describe the concrete steps that the department plans to take to recruit a more diverse workforce. See Michael Butler, Cleveland Div. of Police, Cleveland Division of Police Staffing Report (2017), http://www.city.cleveland.oh.us/sites/default/files/forms_publications/PublicStaffingPlan.pdf [https://perma.cc/3VDT-QLAA]; City of CleVeland, City of Cleveland SAFETy Forces Five-
} 
compliance, few would argue that it is in fact preferable to have no rules at all.

\section{The Undemocratic Character of Administrative Rulemaking}

Another frequent criticism has been that rulemaking is not democratic enough. ${ }^{80}$ Some scholars have pointed out that regimented rulemaking procedures do not allow for much of a back-and-forth between the public and the police. ${ }^{81}$ Or that those most affected by policing practices are unlikely to make their way through dense policies and submit written comments. ${ }^{82}$ Others have argued that the public comment period typically comes too late in the process, after the agency has largely decided on its preferred course of conduct. ${ }^{83}$

Police rulemaking proponents in turn have suggested a number of ways to make rulemaking procedures more democratic, more timely, and more accessible to the public at large. Agencies could, for example, hold community meetings instead of soliciting written comments - and they could hold these meetings directly in the neighborhoods that are most likely to experience policing's effects. ${ }^{84}$ Alternatively, agencies could create advisory councils or "deliberative panels" made up of residents from different backgrounds to ensure all voices are heard. ${ }^{85}$ Or they could make the public comment process more accessible by creating short surveys that ask residents to weigh in on some of the key tradeoffs involved in any particular policy. ${ }^{86}$ And of course, agencies could be required to check in

YEAR RECRUITMENT PlAN (2017). The NYPD, meanwhile, published detailed training curricula on stop and frisk and bias-free policing as part of its own court-ordered reforms. See Training, NYPD MONITOR, http://nypdmonitor.org/reportsandotherdocuments/training/ [https://perma.cc/J6AN-XMM6].

80 See, e.g., Luna, supra note 7, at 599-600 (calling for a "floor of procedural justice" that would promote transparency in criminal law rulemaking); Simmons, supra note 11, at 402-04.

81 See Simmons, supra note 11, at 404.

82 See generally David Thatcher, Equity and Community Policing: A New View of Community Partnerships, 20 CRIM. J. ETHICS 3, 3 (2001) (noting generally that not all members of the community are equally positioned to make their voices heard).

${ }^{83}$ Simmons, supra note 11, at 404.

84 See, e.g., Friedman \& Ponomarenko, supra note 10, at 1888 (suggesting community meetings as a possible alternative); Slobogin, supra note 11, at 997 (suggesting CCTV cameras and other surveillance systems could be approved by a "neighborhood council" after "meaningful consultation with the affected populace").

85 See, e.g., Miller, supra note 11, at 550 (proposing deliberative panels with equal voice to all affected parties as a more democratic alternative); Simmons, supra note 11, at 425 (praising the use of stakeholder groups as part of the Cincinnati collaborative reform effort).

${ }^{86}$ The Policing Project, where I serve as Deputy Director, helped the NYPD draft such a survey to obtain input on its body-worn camera policy. See also Simmons, supra note 11, at 425 (pointing to the use of questionnaires as part of the Cincinnati collaborative reform effort). 
with the public at an earlier point in time to ensure that the input has a greater chance of having an effect. ${ }^{87}$

\section{Resource Constraints}

Finally, a number of scholars have acknowledged that most policing agencies lack the resources and sophistication necessary to comply with an APA-style rulemaking regime. The United States has nearly 18,000 law enforcement agencies, nearly half of which employ fewer than ten officers. ${ }^{88}$ It simply "is implausible that each of these jurisdictions is going to be able to adopt federal notice-and-comment rulemaking procedures." 89

But this objection, too, is hardly fatal. Professor Slobogin notes, for example, that smaller agencies could "piggyback on policies developed by their larger counterparts" — or, as already happens, purchase their policies off the shelf. ${ }^{90}$ And there are plenty of models for how agencies in smaller municipalities could solicit feedback..$^{91}$ The Chicago suburb of Park Ridge, Illinois, for example, has twenty-three commissions and task forces to facilitate public input on everything from public libraries to historic preservation. There is no reason to think that these sorts of governance structures could not be adapted to facilitate greater engagement between communities and their police..$^{92}$ As we wrote in Democratic Policing, " $[\mathrm{t}] \mathrm{he}$ challenge is going to be figuring out how to elicit community participation in communities of all sizes. But this is a beneficial challenge, not a disheartening one." ${ }^{93}$

\footnotetext{
${ }^{87}$ See, e.g., Friedman \& Ponomarenko, supra note 10, at 1888 (suggesting community meetings as a possible alternative); Simmons, supra note 11, at 404 (proposing a more "bottom-up" model of rulemaking); Slobogin, supra note 11, at 997 (suggesting CCTV cameras and other surveillance systems could be approved by a "neighborhood council" after "meaningful consultation with the affected populace").

88 Brian A. Reaves, Bureau of Justice Statistics, Dep't of Justice, Census of State and LOCAL LAW ENFORCEMENT AGENCIES, 2008, at 2 (2011), https://www.bjs.gov/content/pub/pdf /csllea08.pdf [https://perma.cc/53H3-2M9J].

${ }^{89}$ Friedman \& Ponomarenko, supra note 10, at 1886; see also Luna, supra note 7, at 599 (acknowledging that traditional rulemaking may be too cumbersome); Slobogin, Policing as Administration, supra note 9, at 135 (noting that smaller departments "might have great difficulty constructing and explaining rules.").

90 Slobogin, Policing as Administration, supra note 9, at 135. On the use of purchased policies, see Ingrid V. Eagly \& Joanna C. Schwartz, Lexipol: The Privatization of Police Policymaking, 96 TEX. L. REV. 891 (2018).

91 Friedman \& Ponomarenko, supra note 10, at 1888.

${ }^{92} \mathrm{Id}$.

${ }^{93} I d$.
} 
In sum, scholars have over the years pointed to a variety of problems with policing - and they have argued forcefully that many of these problems stem from our failure to subject policing agencies to the same administrative constraints that prevail throughout the regulatory state. Although they have at times acknowledged the various obstacles that their proposals would face, the conventional case against police rulemaking has done little to shake the perception that administrative rulemaking, or its more democratic alternatives, is the solution to policing's various ills.

\section{GOVERning POLICING THROUGH ADMINISTRATIVE RULES}

The real problem with proposals to extend administrative rulemaking to the policing space is that policing agencies are fundamentally different from the sorts of agencies in which rulemaking predominates. The differences between policing agencies and more traditional administrative agencies poses four sets of challenges to the viability of any police rulemaking regime.

First, perhaps the biggest obstacle to police rulemaking is that unlike traditional administrative agencies, policing agencies often lack the incentive to adopt rules in the first place. Second, although a legislature could require policing agencies to write rules, in practice, this often would be quite difficult to do. Even if they do adopt rules, a third concern is the increased challenge in the policing context of specifying when a department should be required to obtain public input on those rules. Finally, it is much harder for the public to meaningfully affect policing outcomes by weighing in periodically on police department rules. In short, although rulemaking may be a promising strategy for regulating certain aspects of policing, like the use of surveillance technologies, it is likely to fall considerably short in most.

\section{A. Why Policing Agencies Adopt Rules (and Why They Don't)}

The public will not have an opportunity to comment on the rules that govern policing unless the department decides to adopt rules in the first place. This may seem obvious - and yet this crucial point often is overlooked. This Section explains that notice-and-comment rulemaking requirements work relatively well in the traditional administrative agency context because agencies have strong incentives to write rules. For policing agencies, however, the incentives to write rules are quite a bit weaker. Left to their own devices, policing agencies are unlikely to adopt the sorts of rules that are needed to address the various problems that have plagued policing for decades.

When scholars argue that policing should be governed through rulemaking, what they typically have in mind are these notice-and-comment 
provisions of the Federal APA. As is common knowledge, the APA requires agencies to make certain kinds of rules available for public comment. ${ }^{94}$ Agencies are then required to respond to the substance of whatever comments they receive before the rules can go into effect. ${ }^{95}$ This back-andforth of comments and responses becomes the basis for judicial review. ${ }^{96}$ Some policing scholars, like Professor Davis, have been explicit in urging this federal model. ${ }^{97}$ Others have acknowledged that federal rulemaking procedures may be too elaborate for the nation's 18,000 police departments, and have argued in favor of "a relaxed administrative-type rulemaking process" that still shares some of the key features of the federal regime. ${ }^{98}$

What these scholars largely have failed to take account of, however, is that the APA does not require agencies to adopt rules in the first place. Under the longstanding principle that the Court first announced in S.E.C. v. Chenery Corp. (Chenery II), it largely falls within an agency's discretion to decide whether to simply enforce a statute as written, or whether to clarify or elaborate upon the statute by issuing a rule. ${ }^{99}$ An agency may sometimes be required to adopt a rule because the statute that it enforces is not selfexecuting - which is to say that until an agency adopts a rule, the statute itself has no effect. ${ }^{100}$ But by and large, agencies have a great deal of discretion in

94 5 U.S.C. §553(b)-(c) (2012); see also Lisa Schultz Bressman, Beyond Accountability: Arbitrariness and Legitimacy in the Administrative State, 78 N.Y.U. L. REV. 461, 541-42 (2003) (describing the function of rulemaking); Robert L. Rabin, Federal Regulation in Historical Perspective, 38 STAN. L. REV. 1189, 1295-1315 (1986) (describing evolution of rulemaking procedures). The APA exempts certain kinds of rules from these requirements, including informal agency guidelines, as well as "internal" rules that bind agency officials but not the public. These lines are hardly clear, and there is a cottage industry of scholarship and case law devoted to making sense of these distinctions. See, e.g., Robert A. Anthony, Interpretive Rules, Policy Statements, Guidances, Manuals, and the Like-Should Federal Agencies Use Them to Bind the Public?, 41 DuKE L.J. 1311, 1321-27 (1992); Jacob E. Gersen, Legislative Rules Revisited, 74 U. CHI. L. REV. 1705, 1719 (2007); John F. Manning, Nonlegislative Rules, 72 GEO. WASH. L. REV. 893, 917-23 (2004).

95 Id.

96 See, e.g., United States v. Nova Scotia Food Prods. Corp., 568 F.2d 240, 252-53 (2d Cir. 1977) (invalidating a rule because the agency failed to adequately respond to public comments).

${ }^{97}$ DAVIS, supra note 1, at 80; see also Slobogin, Policing as Administration, supra note 9, at 134 (using the APA as "the template for discussing the types of restrictions that administrative law might place on panvasive police actions"); Walker, supra note 7, at 389 (calling for police rulemaking statutes that draw on the APA).

${ }^{98}$ Luna, supra note 7, at 603; see also Friedman \& Ponomarenko, supra note 10, at 1886-87 (discussing the merits and scalability of administrative-type rulemaking processes for police departments); Simmons, supra note 11, at 402-03.

99332 U.S. 194, 203 (1947); see also Bressman, supra note 94, at 534-35 (noting enduring commitment to Chenery II even among those who favor greater rulemaking).

100 See Alan B. Morrison, The Administrative Procedure Act: A Living and Responsive Law, 72 VA. L. REv. 253, 256 (1986) (noting that because certain statutes "leave the development of substantive standards to the relevant agencies, they specifically or effectively require rulemaking"). The Clean Air Act, for example, requires the EPA to set emission standards for any substance it considers to be an "air 
deciding whether or not to adopt rules. ${ }^{101}$ To some extent, because the APA imposes costly procedural requirements on agency rulemaking, it actually discourages agencies from adopting or modifying their rules. ${ }^{102}$

Yet, despite the fact that rulemaking is mostly discretionary - and often costly - federal agencies still issue lots and lots of rules. The Department of Health and Human Services issued ninety-two "significant" rules in 2016 alone - and many more technical regulations that were narrower in their effect. ${ }^{103}$ The Transportation Department and the Environmental Protection Agency each issued twenty-eight significant rules in that same time period. ${ }^{104}$ Federal agencies have also issued thousands of interpretive rules, guidance documents, and policy circulars, which are exempt from the notice-andcomment provisions of the APA but still are not entirely costless to draft and adopt. ${ }^{105}$ Agencies, in short, are awash in rules.

Traditional agencies adopt rules primarily for two reasons: because rules make it easier for agencies to govern the public, and because rules make it easier for agencies to govern themselves. As the rest of this Section makes clear, the first of these rationales simply does not apply to policing agencies. The second may be more apt to the policing context—but it is not sufficient,

pollutant.” Clean Air Act (CAA) § 202(a)(1), 42 U.S.C. § 7521(a)(1) (2012). Until the EPA designates a substance to be a pollutant - and sets an appropriate emission standard - there is no law on the books for the EPA to enforce.

101 See M. Elizabeth Magill, Agency Choice of Policymaking Form, 71 U. CHI. L. REV. 1383, 1408 (2004) (noting that agencies have a great deal of discretion whether to proceed by rulemaking or adjudication).

102 See, e.g., Adam B. Cox \& Cristina M. Rodríguez, The President and Immigration Law Redux, 125 YALE L.J. 104, 218-19 (2015). Some critics have described this as a problem of "ossification." Jody Freeman, Collaborative Governance in the Administrative State, 45 UCLA L. REV. 1, 9 (1997); Thomas O. McGarity, Some Thoughts on "Deossifying" the Rulemaking Process, 41 DuKE L.J. 1385, 1387 (1992).

103 See Federal Register, www.federalregister.gov (limiting search by "rule," deemed "significant," published in 2016, by Health and Human Services). A rule is considered a "significant regulatory action" if it has an annual effect on the economy of $\$ 100$ million or more, interferes with the actions of another agency, materially alters the budgetary impact on recipients or otherwise, or raises novel legal or policy issues. Exec. Order No. 12866, 58 C.F.R. § 2(f) (1993).

104 See Federal Register, www.federalregister.gov (limiting search by "rule," deemed "significant," published in 2016, by Department of Transportation, and Environmental Protection Agency).

105 See Nina A. Mendelson, Regulatory Beneficiaries and Informal Agency Policymaking, 92 CoRNELL L. REV. 397, 399 (2007) (pointing out that the EPA issued some 2,000 guidance documents between 1996 and 1999); Richard J. Pierce, Jr., Rulemaking and the Administrative Procedure Act, 32 TULSA L.J. 185, 185 (1996) (noting that "[e]very major agency has a file room full of . . . staff manuals, design criteria, advisories, policy statements, enforcement guides" and the like). These informal rules sometimes are subject to procedural requirements imposed by other federal statutes and executive orders, such as the Paperwork Reduction Act-which means that although they are "cheaper" for agencies to issue, they are not necessarily costless. See Erica Seiguer \& John J. Smith, Perception and Process at the Food and Drug Administration: Obligations and Trade-Offs in Rules and Guidances, 60 FOOD \& DRUG L.J. 17, 19 (2005) (pointing to a number of other federal statutes that regulate the development of rules). 
on its own, to encourage policing agencies to adopt rules in all of the circumstances in which we as a society might want them.

\section{Policing Rules to Govern Us?}

One reason that traditional agencies adopt rules is because rules often make it easier for agencies to accomplish their regulatory goals. Although Congress sometimes regulates with a great deal of specificity, many of the statutory provisions that agencies enforce can be quite broad. ${ }^{106}$ Statutes routinely use terms like "adequate," "prominent," and "fair and equitable."107 From an agency's perspective, there are a number of advantages to reducing these vague standards to more specific rules. Rules promote greater compliance with legal norms by making clear to regulated entities what the law requires. ${ }^{108}$ Rules also reduce agency enforcement costs. ${ }^{109}$ Once an agency adopts a valid legislative rule, it no longer needs to prove in subsequent enforcement proceedings that the conduct at issue violates the underlying statute, only that it runs afoul of the agency rule. ${ }^{110}$ It is much easier for an agency to prove that a seven-foot fence is less than eight feet tall than it is to prove that the seven-foot fence is not the "appropriate" height to safely contain a lion. ${ }^{111}$ Rules, in short, often make it easier for an agency to get the public to do what the agency wants. ${ }^{112}$

Policing agencies differ from traditional administrative agencies in one very critical but overlooked way: unlike traditional administrative agencies, policing agencies are not authorized to regulate the public through

\footnotetext{
106 See Manning, supra note 94, at 898.

107 See, e.g., 19 U.S.C. $\$ 81$ l(a) (2012) (requiring “[a]dequate slips, docks, wharves ...”); 21 U.S.C. \$352(c) (2012) (requiring certain information to be "prominently placed" on drug labels); see also Manning, supra note 94, at 898 (listing others).

108 See Louis Kaplow, Rules Versus Standards: An Economic Analysis, 42 DUKE L.J. 557, 575 (1992).

109 See id. at 570.

110 Manning, supra note 94, at 931. This only is true of "legislative" rules, of course, and does not apply to interpretive rules or guidance documents.

111 See Hoctor v. U.S. Dep't. of Agric., 82 F.3d 165, 170 (7th Cir. 1996) (using this example to describe interpretation of rules).

112 This does not mean, of course, that agencies always will prefer rules to case-by-case adjudication. Rules may themselves be costly to write. Agencies may be concerned that any rules they adopt will be over- or underinclusive in ways that frustrate agency goals. There is a rich literature on the relative merits of articulating policy through rules or refining it over time through individual enforcement proceedings. See, e.g., Daniel A. Crane, Rules Versus Standards in Antitrust Adjudication, 64 WASH. \& LEE L. REV. 49, 83-90 (2007) (discussing this problem in the context of antitrust enforcement). But see Kaplow, supra note 108, at 593-96 (questioning the assumption about the relative over- or underinclusiveness of rules). What matters for present purposes is that agencies often benefit from having rules — which makes agency rules a logical focal point for public oversight.
} 
department rules. ${ }^{113}$ Police are charged with enforcing the criminal law, but they are not permitted to alter its scope. A police department could not issue a rule banning certain kinds of drug-related activities - or permitting others-and expect a court, or anyone else for that matter, to enforce it. ${ }^{114}$ The only obligations that policing agencies enforce are those that legislatures themselves adopt. The obligation to stop or pull over in response to a lawful police order, for example, does not derive from police department policy but rather from a state's substantive criminal law. ${ }^{115} \mathrm{~A}$ department rule could not formally narrow or expand that obligation in any way-which means that at least some of the reasons why traditional agencies adopt rules simply do not apply to the police.

Of course, as Professor Davis points out, traditional agencies also issue thousands of interpretive rules, guidance documents, and internal rules that are only binding on agency officials - and there is nothing to stop the police from doing the same. ${ }^{116}$ The Equal Employment Opportunity Commission (EEOC), for example, also lacks the authority to issue binding rules in some contexts, but nevertheless issues nonbinding guidelines with some frequency. ${ }^{117}$ The EEOC uses these guidelines to explain how the agency plans to interpret certain statutory requirements and to make clear to regulated entities what they must do in order to comply. Likewise, a police department could announce that it will only enforce marijuana possession laws against individuals caught smoking marijuana in public, or that motorists will not be pulled over for certain kinds of equipment violations if that is the only offense.

But even when it comes to these sorts of rules and guidelines, policing agencies have fewer incentives than do traditional administrative agencies to adopt them. This is because even when traditional agency rules are not binding on the public, they still help agencies regulate the public in ways policing rules simply do not.

Much of the difference between traditional agency rules and police department rules has to do with the comparative content of civil and criminal

113 See Ronald J. Allen, The Police and Substantive Rulemaking: A Brief Rejoinder, 125 U. PA. L. REV. 1172, 1178 (1977) (pointing out that police lack authority to adopt binding rules); Davis, supra note 67, at 707 (acknowledging that police lack authority to adopt binding rules).

114 See, e.g., Dan M. Kahan, Is Chevron Relevant to Federal Criminal Law?, 110 HaRv. L. REv. 469, 490 (1996) (noting that courts have traditionally refused to defer to enforcement agency interpretations of the criminal law).

115 See, e.g., FLA. STAT. § 316.072(3) (2018) (making it a misdemeanor to disobey an officer's lawful order when driving, biking, or wherever vehicles can travel).

116 Davis, supra note 67, at 707. On the different categories of agency rules and guidance documents, see Anthony, supra note 94, at 1321-26.

117 See Magill, supra note 101, at 1387-88. 
law - and by extension, the function that agency rules perform. One of the defining features of many civil regulatory statutes is their ambiguity. ${ }^{118}$ Terms like "equitable" or "hazardous" are susceptible to any number of reasonable interpretations, and absent agency guidance, regulated entities may come to very different conclusions about what the law requires. ${ }^{119}$ If an agency wants the public to conform in a particular manner, it may help to announce its preference through guidelines or interpretive rules. Another key feature of civil regulatory statutes is their complexity. ${ }^{120}$ Agency guidelines can help clarify what is required, thereby ensuring that those who wish to comply with the law can do so. ${ }^{121}$ Studies suggest that in practice, this is precisely what occurs: even when agency guidelines are nonbinding, regulated entities tend to alter their conduct in response. ${ }^{122}$

In contrast, the defining feature of criminal law is not its ambiguity (or its complexity) but rather its breadth. ${ }^{123}$ There are exceptions, to be sure, particularly when it comes to federal criminal prohibitions against bribery, securities fraud, and other white-collar offenses. ${ }^{124}$ But the chief criticism against most ordinary criminal statutes, such as the laws prohibiting gambling, drinking in public, or smoking marijuana, is not that they are unclear. Rather, it is that they criminalize broad swaths of conduct that many people routinely engage in, which gives police a great deal of license to pick and choose when to enforce them. ${ }^{125}$ The same is true of traffic laws, as well as the myriad quasi-criminal administrative codes that police officers also enforce. ${ }^{126}$ The problem is not that people may come to different conclusions

\footnotetext{
118 See Manning, supra note 94, at 898.

119 See Kaplow, supra note 108, at 587-88; Magill, supra note 101, at 1443-45.

120 See Seiguer \& Smith, supra note 105, at 25 (discussing why agencies issue guidelines).

121 See, e.g., Mendelson, supra note 105, at 400 (pointing to an eighty-page guidance document that the EPA issued with "detailed information and instructions" for how to comply with a one-page rule).

122 See Seiguer \& Smith, supra note 105, at 29-30 (noting that industry groups often treat guidelines and rules as analogous).

123 There are a number of reasons for this. First, the Due Process Clause's vagueness doctrinewhich requires that laws be written with sufficient precision to provide notice to the public and avoid the risk of government arbitrariness - operates with much greater force in the criminal context. And over the years, courts have struck down or narrowed a number of criminal statutes on vagueness grounds. See, e.g., Papachristou v. City of Jacksonville, 405 U.S. 156, 162 (1972) (invalidating an ordinance as "void for vagueness"); City of Chicago v. Morales, 527 U.S. 41, 51 (1999) (same). Second, as many have documented, the pathological politics around criminal justice creates strong incentives for legislatures to phrase criminal prohibitions broadly, and then to leave it to police and prosecutors to decide when to apply them. See William J. Stuntz, The Pathological Politics of Criminal Law, 100 MICH. L. REV. 505, 546-57 (2001) (describing legislators' incentives to define the substantive criminal law broadly).

124 See Kahan, supra note 114, at 473-74 (noting the breadth and ambiguity of some federal whitecollar statutes).

125 See Luna, supra note 7, at 522-23.

126 See, e.g., David A. Harris, "Driving While Black” and All Other Traffic Offenses: The Supreme Court and Pretextual Traffic Stops, 87 J. CRIM. L. \& CRIMINOLOGY 544, 557-58 (1997).
} 
about what constitutes jaywalking, driving with a broken taillight, or failing to come to a complete stop. The problem is that there are so many laws on the books that virtually everyone is susceptible to being stopped at any time.

For this reason, the sorts of substantive enforcement guidelines that scholars have urged policing agencies to adopt are not designed to clarify the criminal law, but rather to narrow its scope. Professor Davis pointed out, for example, that Chicago police officers distinguished between "social" and "commercial" gambling and only enforced gambling laws against the latter. ${ }^{127}$ They also rarely, if ever, enforced laws against riding a bicycle on a sidewalk, jaywalking, or even smoking marijuana in public. ${ }^{128}$ It was precisely these sorts of decisions that Professor Davis urged departments to formalize through binding rules. ${ }^{29}$ As discussed below, there may be other reasons why policing agencies would find these sorts of guidelines valuable internally - but it is not because they help police enforce the criminal laws by making clear to the public what the laws require. ${ }^{130}$ Indeed, there is every reason for the police to avoid adopting these rules so as not to provide the public with a guidepost for how to engage in conduct that the legislature has deemed impermissible.

Rules, in short, do not make it easier for the police to govern us - which means that the operative question is whether and when policing agencies need rules to govern themselves. Once the question is framed in this manner, it becomes much easier to predict when policing agencies are likely to have rules and when they are not.

\section{Policing Rules to Govern Themselves?}

Traditional agencies also adopt rules in order to guide and constrain the actions of agency staff. All agencies need some rules simply to function in

127 DAVIS, supra note 4, at 5.

128 Id. at 5-6.

129 Id. at $98-112$.

130 The same is true when it comes to police rules that govern the methods that officers use in enforcing the law. A number of scholars, including Professors Christopher Slobogin and Tracey Meares, have argued that certain investigative tactics, like programmatic stop and frisk or suspicionless surveillance, are in fact "regulatory" because they force law-abiding residents to choose between giving up their liberty or privacy and taking various measures to avoid unwanted contact with the state. See Tracey L. Meares, Programming Errors: Understanding the Constitutionality of Stop-and-Frisk as a Program, Not an Incident, 82 U. CHI. L. REV. 159, 162-63 (2015); Slobogin, Policing as Administration, supra note 9 , at 96 . In heavily policed communities, some residents have responded to pervasive streetlevel enforcement or surveillance by changing how they dress, where they walk, how they conduct themselves, and with whom they interact. See, e.g., Craig B. Futterman et al., Youth/Police Encounters on Chicago's South Side: Acknowledging the Realities, 51 GA. L. REV. 1079, 1104-06 (2017). The important point to note, however, is that the regulatory effect of these invasive tactics comes from the practices themselves - as opposed to the agency rules to govern their use. The public responds to what the police $d o$, not to what police rules say. 
an orderly manner. Rules promote uniformity and increase the likelihood that like cases will be treated alike. ${ }^{131}$ Rules and guidelines also make it easier for agency heads to impose their will on sprawling - and often far-flungbureaucracies. ${ }^{132}$ The vast majority of agency staff members are career officials who may hold views that are inconsistent with those of whatever administration currently is in power. ${ }^{133}$ Rules and guidelines help ensure that low-level officials act more in accordance with the wishes of agency heads. ${ }^{134}$

Many of these reasons apply to policing agencies as well. Like traditional agencies, policing agencies rely on rules to ensure orderly function, addressing issues like organizational structure, chain of command, handling of equipment, grievance procedures, and paid leave. Police department manuals devote hundreds of pages to just these sorts of rules. ${ }^{135}$ And like all agencies, policing agencies benefit from having at least some internal rules to guide how officers behave out in the field. Additionally, they may implement rules to limit legal liability. But, as this Section makes clear, police departments often lack the incentive to adopt the sorts of rules needed to address the problems identified in Part I.

\section{a. Cabining Line Officer Discretion}

One reason why policing agencies may want to adopt rules is to ensure that officer-level decisions reflect the policy preferences of agency heads. Chiefs may have strong views about how officers should conduct themselves. For example, chiefs have tended to be more progressive, or at least more supportive of innovation, than have the rank-and-file. ${ }^{136}$ Police executive organizations, like the Police Executive Research Forum, have supported reform efforts across a variety of domains, including use of surveillance technology and the use of force. ${ }^{137}$ Department rules are one way that chiefs can impose these views on the agency as a whole.

\footnotetext{
131 See Bressman, supra note 94, at 541-42 (justifying rulemaking on this basis).

132 See Manning, supra note 94, at 915.

133 See Barkow, supra note 25, at 1155.

${ }^{134} \mathrm{Id}$.

135 See, e.g., Austin Police DePartment Policy Manual (2017), https://www.austintexas.gov /sites/default/files/files/Current_APD_Policy_Manual_2017-1.5_issued_7-20-2017.pdf [https://perma.cc/A2YP-3U76] (devoting hundreds of pages to personnel and equipment policies). This was true even in the 1960s. See PRESIDENT's COMM'N, Challenge OF CRIME In A FREE SOCIETY, supra note 5 , at 103 .

136 See, e.g., Richard Pérez-Peña \& Sheryl Gay Stolberg, Police Unions Hail Trump's Easing of Scrutiny. Local Officials Worry., N.Y. TimeS (Apr. 4, 2017), https://www.nytimes.com/2017/04/04/us /trump-police-unions-obama-justice-department-doj.html [https://perma.cc/R2HU-P3PB] (pointing to divergence between chiefs and rank-and-file over Justice Department reforms).

137 Police Exec. Research Forum, Costs and Benefits of Body-Worn CAMERA DEPLOYMENTS: FINAL REPORT (2018), http://www.policeforum.org/assets/BWCCostBenefit.pdf [https://perma.cc/43J3-82HZ]; POLICE EXEC. RESEARCH ForuM, GUIDING PRINCIPLES ON USE OF FORCE
} 
An important countervailing force, however, is that policing agencies also often benefit from giving officers greater leeway to decide which laws to enforce and when. In the hands of the officer, the breadth of criminal law is itself a potent tool. As Professor David Harris notes, "with the traffic code in hand, any officer can stop any driver any time." 138 This means that an officer who suspects a motorist, for whatever reason, of being involved in criminal activity, but lacks the requisite suspicion to stop the person on that basis, can instead pull the driver over for a minor infraction and investigate further. Even if an officer does have reasonable suspicion, the officer may still prefer to wait for a violation in order to avoid having to litigate the matter at a subsequent suppression hearing. These sorts of pretextual stops have been sharply criticized by civil liberties groups, academics, and occasionally the courts. ${ }^{139}$ But they unfortunately are common, and commonly encouraged by department brass. ${ }^{140}$

Discretion might be more of a problem for policing agencies were it not for the fact that those who bear the brunt of excess discretion typically are not in a position to make things politically difficult for chiefs. The unfortunate reality is that the costs of discretion tend to fall disproportionately on communities that are marginalized politically. ${ }^{141}$ Professor James Forman Jr. points out, for example, that in majority-black Washington, D.C., the sorts of policing practices that were the norm in poor black neighborhoods were never used in the more affluent black neighborhoods where residents were in a better position to complain. ${ }^{142}$

There also are countervailing political pressures that may further discourage rulemaking. Officers and their unions are a potent political force, which may make chiefs reluctant to adopt guidelines or policies that officers

(2016), http://www.policeforum.org/assets/30\%20guiding\%20principles.pdf [https://perma.cc/Y6CKRAAN].

138 Harris, supra note 126, at 559; see also Tracey Maclin, Race and the Fourth Amendment, 51 VAND. L. REV. 333, 376-79 (1998).

139 See, e.g., Utah v. Strieff, 136 S. Ct. 2056, 2065-66 (2016) (Sotomayor, J., dissenting); Harris, supra note 126, at 560 (arguing that police will use their power to conduct pretextual stops "mostly to stop African-Americans and Hispanics").

140 See, e.g., Gideon's ARMY \& NAShVille CMty. ORgs. \& LEADERs, Driving While Black: A Report on Racial Profiling in Metro Nashville Police Department TrafFic Stops 25 (2016), https://drivingwhileblacknashville.files.wordpress.com/2016/10/driving-while-black-gideons-army.pdf [https://perma.cc/J5XK-Z976] (finding that Nashville officers were trained to make low-level stops and then try to obtain consent to search vehicles for drugs or contraband).

141 See Donald A. Dripps, Criminal Procedure, Footnote Four, and the Theory of Public Choice; Or, Why Don't Legislatures Give a Damn About the Rights of the Accused?, 44 SYRACUSE L. REV. 1079, 1089 (1993).

142 JAMES FORMAN JR., LOCKING UP OUR OWN: CRIME AND PUNISHMENT IN BLACK AMERICA 20911 (2017). 
will oppose. ${ }^{143}$ Moreover, chiefs may simply not want to stick their necks out by adopting enforcement guidelines and other policies that draw public attention to the department's practices. ${ }^{144}$ The reason why scholars are in favor of rules - to increase salience and ensure greater political accountability - is the same reason why chiefs ultimately may be reluctant to voluntarily adopt them.

In any event, rules are just one way that police officials shape officer behavior. Department leadership can communicate their priorities through CompStat meetings, roll call, training, officer evaluations, and direct orders down the chain of command. ${ }^{145}$ A policing agency cannot conduct its business entirely through word of mouth. But in many cases these alternative mechanisms may be just as effective at making the department's preferences known. This is particularly true in contexts where rules may be difficult to write with any degree of precision or are likely to attract the sort of attention that chiefs might prefer to avoid.

\section{b. Avoiding Legal Liability}

Another reason why police departments sometimes may want to adopt rules is financial: to avoid the costs associated with lawsuits and complaints that may arise as a result of officer misconduct. The potential threat of legal liability, however, can both encourage and discourage agency rules.

Under the rule announced in Monell v. Department of Social Services of New York, agencies are not directly liable for officer misconduct. ${ }^{146}$ The familiar doctrine of respondeat superior does not apply when government agents are sued for violating a person's constitutional rights. Agencies are held liable only if plaintiffs can show that an officer's misconduct resulted directly from an established agency policy. Monell also potentially creates a perverse incentive for agencies to avoid putting certain policies in writing, lest the policies themselves be found to run afoul of constitutional law.

The significance of Monell, however, is diminished by the fact that the vast majority of agencies indemnify their officers against any liability that the officers personally may face. ${ }^{147}$ As a result, even if agencies are not

\footnotetext{
143 See Dripps, supra note 141, at 1091; Catherine L. Fisk \& L. Song Richardson, Police Unions, 85 GEO. WASH. L. REV. 712, 744-47 (2017).

144 Luna, supra note 7, at 608.

145 See Floyd v. City of New York, 959 F. Supp. 2d 540, 591-602 (S.D.N.Y. 2013) (describing a range of ways that officials communicated priorities to officers).

146436 U.S. 658, 691 (1978).

147 Joanna C. Schwartz, Police Indemnification, 89 N.Y.U. L. REV. 885, 885 (2014) (finding that governments "paid approximately $99.98 \%$ of the dollars that plaintiffs recovered in lawsuits alleging civil rights violations by law enforcement").
} 
themselves held liable, they still are likely to pay. ${ }^{148}$ This puts at least some pressure on agencies to develop policies that reduce the likelihood of misconduct that could lead to large damage awards. ${ }^{149}$ In fact, there now are companies like Lexipol, which specialize in developing off-the-shelf policies for law enforcement agencies that minimize agencies' financial risks. ${ }^{150}$

Concerns with possible legal liability, however, are limited to a fairly narrow set of police policy domains. First, legal liability arises primarily in areas that already are governed by statutory or constitutional law. But constitutional law has almost nothing to say about police use of enforcement discretion. ${ }^{151}$ Nor does the Constitution do much to regulate surveillance that falls short of a "search" within the meaning of the Fourth Amendmentwhich under current law includes CCTV cameras, license plate readers, social media monitoring, and at least some collection of personal data from third parties. ${ }^{152}$ Statutory law around policing is equally thin. ${ }^{153}$ Second, as Professor John Rappaport has pointed out, the threat of legal liability is more likely to spur agency policymaking in circumstances in which officer misconduct could lead to large damage awards, like use of force. ${ }^{154}$ Financially minded agencies may be less concerned about unlawful stops and arrests or the misuse of surveillance technology, which typically involve lower value claims and are less often litigated. ${ }^{155}$

148 Of course, as Professor Joanna Schwartz points out, these financial signals may be muted by the fact that agencies do not always pay these costs directly, because they are paid either by municipal insurers or out of municipal general funds. Joanna C. Schwartz, How Governments Pay: Lawsuits, Budgets, and Police Reform, 63 UCLA L. REv. 1144, 1173-78, 1188 (2016).

149 Id. at 1188-92.

150 See Eagly \& Schwartz, supra note 90, at 923-29.

151 See Barkow, supra note 25, at 1135 ("Police officers and prosecutors possess enormous discretion over whom to stop, arrest, and charge - and for what. Courts largely sit on the sidelines."); MarianoFlorentino Cuéllar, Auditing Executive Discretion, 82 NOTRE DAME L. REv. 227, 227 (2006) (noting that courts rarely review decisions about which laws to enforce and against whom).

152 See Friedman \& Ponomarenko, supra note 10, at 1871-75. The Court is gradually adjusting the definition of a search to capture certain kinds of surveillance technologies but is unlikely to ever keep up with the rapid pace of technological change. See, e.g., Carpenter v. United States, 138 S. Ct. 2206, 2220 (2018) (holding that acquiring long-term cell-site location data from a third party constitutes a search); United States v. Jones, 565 U.S. 400, 413 (2012) (holding that long-term GPS surveillance constitutes a search).

153 See Friedman \& Ponomarenko, supra note 10, at 1843 (arguing that there is "remarkably little legislative direction for America's policing officials").

154 John Rappaport, An Insurance-Based Typology of Police Misconduct, 2016 U. CHI. LEGAL F. 369, 376-77 (2016).

${ }^{155} I d$. at 395-97. Agencies still face the possibility of costly injunctive suits, which may encourage proactive policymaking to some degree. See, e.g., Floyd v. City of New York, 959 F. Supp. 2d 540, 667 (S.D.N.Y. 2013) (holding that New York City's stop and frisk policy is unconstitutional and noting the need for "immediate changes to the [NYPD's] policies"). 


\section{When Policing Agencies Have Rules}

In view of the complex incentive structure facing policing agencies, one would expect a great deal of variance in the degree to which various aspects of policing are governed through rules. Given liability concerns, for example, one would expect agencies to have at least some policies around the use of force. On the other hand, one would expect to see few if any rules to cabin enforcement discretion, because policing agencies rarely benefit from having these sorts of rules. Rules concerning the use of surveillance technologies could go either way. Agencies may be less concerned with legal liability, both because surveillance tends to fall beyond the reach of constitutional law, and because damages from any instances of misconduct are likely to be quite small. But because surveillance typically is aimed at a broader subset of the public, chiefs may face greater political pressure to make clear how the technologies are to be used.

In practice, this is precisely what we get. Most if not all agencies have rules for when force may be used, as well as how it must be documented and reviewed. ${ }^{156}$ These policies may not be very good and may be missing critical elements-but arguably that is what public rulemaking procedures are supposed to fix. ${ }^{157}$ On the other hand, policies on the use of surveillance technologies, like automated license plate readers (ALPRs) and drones, tend to be more hit or miss. Studies suggest that although many agencies do in fact have policies on various technologies, others do not. ${ }^{158}$ One study, for example, found that just seventeen of the fifty-three agencies in Massachusetts that used ALPRs had written policies regarding their use. ${ }^{159}$ But again, as is true for use of force, there is at least some likelihood of finding agency policies that directly contribute to how these technologies are used.

156 See Garrett \& Stoughton, supra note 78, at 263-68 (describing key features of agency use of force policies).

157 See Bressman, supra note 94, at 541-44.

158 Police EXEC. RESEARCH Forum \& DEP'T OF Justice, OFFICE OF CMTY. ORIENTED Policing SERVS., IMPLEMENTING A BODY-Worn CAMERA PROGRAM: RECOMMENDATIONS AND LESSONS LEARNED 2 (2014), https://www.justice.gov/iso/opa/resources/472014912134715246869.pdf [https://perma.cc/5LGK-DVBE].

159 Shawn Musgrave, License Plate-Reading Devices Fuel Privacy Debate, Bos. GLOBE (Apr. 9, 2013), http://bostonglobe.com/metro/2013/04/08/big-brother-better-police-work-new-technologyautomatically-runs-license-plates-everyone/1qoAoFfgp31UnXZT2CsFSK/story.html

[https://perma.cc/84Y8-LP4C]. In Carlsbad, California, the Electronic Frontier Foundation found that the only "policy" that the department had regarding the use of mobile face recognition technology was a technical manual from the manufacturer. See Dave Maass, Why California Urgently Needs Surveillance Transparency, ELECTRONIC FRONTIER FOUND. (June 6, 2017), https://www.eff.org/deeplinks/2017/06 /why-california-urgently-needs-surveillance-transparency [https://perma.cc/VHT5-J7VC]. 
When it comes to traffic and pedestrian stops, rules play a still more limited role. Virtually every policing agency has a "search and seizure" policy that, more often than not, just restates the constitutional requirement that a stop be based on reasonable suspicion. In most agencies, however, a major driving force behind the use and abuse of traffic and pedestrian stops has been the "policy" of using large numbers of stops as a crime-fighting tool. ${ }^{160}$ And in none of these agencies has this "policy" been announced through anything that looks like a written rule. In New York City, for example, the plaintiffs in Floyd had to rely on circumstantial evidence, including notes from CompStat meetings, secret recordings, and officer surveys, to prove that the NYPD put pressure on officers to make large numbers of stops because there was no written policy to that effect. ${ }^{161}$

Predictably, policing agencies have very few rules or guidelines in place to cabin enforcement discretion. Some departments have rules about when officers should issue a summons in lieu of making an arrest - though often these rules simply mirror state laws to that effect. ${ }^{162}$ But by and large even these rules are the exception that proves the rule. Notably absent from police manuals or other department-issued documents are the sorts of substantive enforcement guidelines that Professors Davis, Luna, and other rulemaking proponents have over the years urged policing agencies to adopt. ${ }^{163}$ Nor do agencies typically have rules in place to address the many other factors that influence enforcement outcomes, such as staffing and deployment. In light of the aforementioned discussion, it is easy to see why.

\footnotetext{
160 See infra Part I.

161 Floyd v. City of New York, 959 F. Supp. 2d 540, 591-602 (S.D.N.Y. 2013). The only documents that came close to announcing a policy on aggressive street-level enforcement were two strategy documents that the New York City Mayor's Office and the NYPD issued in 1994, which announced a new emphasis on low-level offenses and gun crimes. N.Y.C. POLICE DEP'T, NCJ 167805, POLICE Strategy No. 1: GetTing Guns OfF the Streets of New York (1994); N.Y.C. Police DeP'T, NCJ 167807, Police Strategy No. 5: Reclaiming the Public Spaces of New York (1994), https://www.ncjrs.gov/pdffiles1/Photocopy/167807NCJRS.pdf [https://perma.cc/AV58-LP93]. However, neither document in fact mentioned the use of stops. Even with the benefit of hindsight, these documents are at best a precursor to the aggressive stop and arrest strategies that the NYPD implemented in the two decades that followed.

162 See, e.g., OAKLANd POlice DeP'T, General ORder M-7: Citations fOR Adult MISDEMEANORS 2-3 (1996), http://www2.oaklandnet.com/oakca1/groups/police/documents/webcontent /oak058222.pdf [https://perma.cc/XK7V-44NG] (describing a presumption in favor of a citation in lieu of arrest for misdemeanor offenses and listing the circumstances under which the presumption may be overridden as a matter of state law).

163 See, e.g., DAVIS, supra note 4; Livingston, supra note 7, at 658-63; Luna, supra note 7, at 60304.
} 
Procedural rulemaking requirements along the lines of the Federal APA only work if agencies have an incentive to adopt rules in the first place. And because rulemaking procedures impose some additional costs on agencies, one would expect policing agencies subject to an APA-style regime to have even fewer rules. In order for rulemaking to have some effect on enforcement discretion - or even some areas of force and surveillance - there would need to be some mechanism in place to require rules. That is what this Article takes up next.

\section{B. Requiring Policing Agencies to Write Rules}

If policing agencies will not issue rules on their own, perhaps they should be made to do so. Over the years, a number of scholars have argued that if policing agencies will not adopt rules voluntarily, legislatures should require it. ${ }^{164}$ As this Section makes clear, however, mandatory rulemaking is most likely to be effective around precisely the sorts of policing practices that already tend to be governed through rules - and much less effective where such rules are absent.

In order to make rulemaking mandatory, a legislative body must be able to specify when a policing agency needs to have a rule. In some cases, this may be fairly simple to do. Recall that in the traditional administrative context, agencies are sometimes required to adopt rules when the statutes they enforce are not self-executing. ${ }^{165}$ For example, before the EPA can regulate a particular substance, it must first adopt a rule declaring it to be a pollutant and setting appropriate emissions standards. ${ }^{166}$ The EPA can of course decide not to regulate the substance at all, but if it wants to act in a particular sphere, it needs the rule in order to do so. ${ }^{167}$ These sorts of

\footnotetext{
164 Professor Samuel Walker, for example, pointed out in 1986 that policing agencies were not exactly rushing to bind themselves through rules, and urged legislatures to require rules around use of force, stop and frisk, and other investigative techniques. Walker, supra note 7, at 382-83. Catherine Crump has argued in favor of mandatory rulemaking — and legislative approval — around police use of various surveillance technologies. Crump, supra note 11, at 1656-59. Both Professors Anthony Amsterdam and Kenneth Culp Davis urged courts to interpret the Fourth and Fourteenth Amendments to require policing agency rules, but courts have by and large dismissed the invitation to do so. DAVIS, supra note 4, at 98-120; Amsterdam, supra note 3, at 416-18. Although Barry Friedman and I pointed out in Democratic Policing where there may be space to push existing law in that direction, it is unlikely that constitutional law will change anytime soon. Friedman \& Ponomarenko, supra note 10, at 1892-1903. For this reason, judicially-mandated rules are largely beyond the scope of this Article. Court-ordered rulemaking also would face many of the same sorts of line-drawing problems discussed here.

165 See Morrison, supra note 100, at 256 (noting that because certain statutes "leave the development of substantive standards to the relevant agencies, they specifically or effectively require rulemaking").

166 Clean Air Act (CAA) § 202(a)(1), 42 U.S.C. § 7521(a)(1) (2012).

167 In Massachusetts v. EPA, the Court imposed some outer limits on these sorts of choices. 549 U.S. 497, 527-28 (2007).
} 
rulemaking requirements are both easy to articulate and, to a large extent, self-enforcing.

For certain aspects of policing, one can imagine an analogous set of requirements. Take, for example, the use of various surveillance technologies. One reason why it may be possible to require rules in this context is because the decision to adopt a new technology involves a discrete change to the status quo. The agency did not have Stingrays (or license plate readers, or predictive policing technology), and then it did. There is a clear "before" and "after" and thus a fixed point in time when the agency may be required to adopt a rule. It perhaps makes sense, then, that surveillance is one area of policing in which legislatures have in fact experimented with requiring police department rules. A small number of cities, including Seattle, Berkeley, and Nashville, have passed ordinances requiring their local police departments to obtain city council approval and adopt a written policy before deploying a new surveillance technology. ${ }^{168}$ In California and Illinois, agencies are required as a matter of state law to have policies in place before deploying certain technologies, such as license plate readers or body-worn cameras. ${ }^{169}$

For other areas of policing, however, a rulemaking requirement would be much harder to devise. Consider for example the NYPD's "policy" of using large numbers of stops to drive down crime. It is hard to imagine a rulemaking requirement that would have forced the department to announce this policy in the form of an ex ante rule. Over the years, NYPD commanders made a number of decisions-about staffing, deployment, officer evaluations, and department strategy - that ultimately resulted in the set of practices that plaintiffs challenged in Floyd. But there was no fixed point in time when the NYPD went from not using stops at all to using them en masse. ${ }^{170}$ Unlike new surveillance technologies, stops are a tool that officers have always had at their disposal. The changes that took place were a matter of degree. Even in retrospect, it is not clear at what point the NYPD ought to have adopted a rule.

The difficulty is greater still when it comes to the use of enforcement discretion, albeit for a different set of reasons. In order to get a police department to cabin officer discretion, the legislature must be able to do two

168 Berkeley, CAL., OrdinANCE 7592 (2018); NAShVille, TENN., ORdinANCE BL2017-646 (June 7, 2017); SEATtLE, WASH., ORdinANCE 124142 (2017).

169 California Automated License Plate Recognition Systems Law, CAL. CIV. CoDE § 1798.29 (2018); Police Community Improvement Act, ILL. COMP. STAT. 727/1-1 (2018).

170 Stop and frisk has of course been used as an investigative tactic for decades. See, e.g., Terry v. Ohio, 392 U.S. 1, 7 (1968). On the evolution of stop and frisk in New York City, see Floyd v. City of New York, 959 F. Supp. 2d 540, 565-69 (2013). 
things: articulate what sorts of rules are required and how specific they must be.

The first is tricky because different criminal statutes raise different kinds of concerns. In some contexts - such as domestic violence or sexual assault - the concern is that police do not take allegations seriously or are more responsive to some classes of victims than they are to others. ${ }^{171}$ When it comes to traffic laws, however, or other low-level offenses, the concern instead is that criminal law sweeps too broadly, which gives police far too much discretion to decide when to enforce them. ${ }^{172}$ The sorts of rules needed to address the former would look quite different than rules to address the latter-and a rulemaking requirement would need to make clear what sorts of rules are needed when.

The greater challenge is that, unless the legislature can also articulate how specific the rules must be, a policing agency could avoid any rulemaking mandate by issuing rules that themselves are models of vagueness and ambiguity. A legislature could, for example, require a police department to develop guidelines to cabin enforcement of certain low-level offenses. The goal of any such requirement would be to get the department to make clear when these laws would not be enforced - or would be enforced through less aggressive means. The problem is that nothing would prevent the department from simply announcing that it takes these laws seriously and plans to enforce them as written (whether or not that is, in practice, what occurs). If the goal is to get a police department to narrow the scope of criminal law, a legislature would need to be able to articulate not only which laws need narrowing but also, importantly, how narrow is narrow enough. It is easy to point to a particular statute and suggest ways in which it could be narrowed. It is much harder, however, to describe a standard for judging a police department's decision to enforce the statute as is. This is precisely why legislatures and courts have typically refrained from imposing rulemaking requirements on traditional agencies as well. ${ }^{173}$

Other areas of policing fall somewhere between the two extremes of surveillance technology and enforcement discretion. It may not be possible to come up with a single rulemaking requirement to ensure that police establish rules across a variety of policy domains. But for critical areas that legislators and the public are most likely to care about - such as use of force or the use of informants - a legislature potentially could enumerate what policies an agency must have. However, doing so would not be without its

171 See Natapoff, supra note 53, at 1731-39.

172 See Harris, supra note 126, at 557-58.

173 See Manning, supra note 94, at 896. Professor John Manning makes this argument in the context of the judicially-enforced Chenery II rule, but the same rationale applies to legislatures as well. 
challenges. To have real bite, such a requirement would likely need to specify not only the topics on which an agency must have a policy in place but also the specific issues that each policy must address. And it would need to be updated as policing evolves in ways that raise new policy concerns. All of this may be possible in theory, but it would require legislators to do more than simply agree, at a particular moment, to change the process through which policing agencies adopt their rules.

Accordingly, if policing agencies decline to issue rules independently, even mandatory rulemaking is unlikely to reach the types of policing problems that are of greatest public concern.

\section{Determining Which Policies Require Public Input}

An additional challenge to implementing a public rulemaking regime around policing is that a legislature would need to be able to specify which policies require public input and which do not. The goal of any such requirement is readily apparent: to ensure that the public has a say in the policies that affect them, while giving the department leeway to proceed more expeditiously for those that are less consequential. However, translating that goal into a rule - or even into a standard — is easier said than done.

At the federal level, the APA requires agencies to go through noticeand-comment rulemaking when they adopt "legislative" rules that impose new obligations on the public or bind the public in some way. ${ }^{174}$ Interpretive rules, guidance documents, and rules having to do with internal agency management are exempt from the notice-and-comment provisions of the APA. ${ }^{175}$ A number of scholars have questioned whether the APA draws the line in the right place, but all agree that a line must be drawn somewhere. ${ }^{176}$ Agencies issue thousands of documents that arguably could be called "rules." Government would grind to a halt if each of these documents were subject to the notice-and-comment requirements of the APA. And in all likelihood, agencies would simply issue far fewer guidance documents and rules, to the detriment of the rule of law values that rules promote. ${ }^{177}$

Although courts have struggled over the years to apply the various distinctions between "legislative" and "non-legislative" rules with any

174 See id. at 893 (citations omitted). The phrase "legislative rule" does not appear in the text of the APA itself, but it has been used by commentators and courts to describe the category of rules to which notice-and-comment requirements apply.

175 See Anthony, supra note 94, at 1323

176 See, e.g., Anthony, supra note 94, at 1355-56; Manning, supra note 94, at 894-96.

177 See David L. Franklin, Legislative Rules, Nonlegislative Rules, and the Perils of the Short Cut, 120 YALE L.J. 276, 306 (2010). 
degree of coherence, ${ }^{178}$ what matters for present purposes is that most if not all police department policies fall well outside the debatable line of what constitutes a "legislative" rule. As Barry Friedman and I explain in Democratic Policing, this is because police rules are internal. ${ }^{179}$ Although police rules can certainly be of great consequence for the public, the police are not permitted, as a matter of law, to bind the public or formally alter the public's rights (i.e., to tell the public itself how to behave). ${ }^{180}$ There may be a narrow subset of police rules that arguably could trigger rulemaking obligations. Some courts, for example, have deemed certain kinds of enforcement guidelines to be "legislative" rules. ${ }^{181}$ But in order to reach the vast majority of police conduct, a rulemaking requirement for policing agencies would need a new standard for distinguishing between those policies that require public input and those that do not.

The first challenge to defining when comment is required in the policing context is deciding what constitutes a policy or rule in the first place. The APA describes a "rule" as "an agency statement of general or particular applicability and future effect designed to implement, interpret, or prescribe law or policy or describing the organization, procedure, or practice requirements of an agency." 182 Such a definition, if applied to the policing context, arguably would reach not only the formal "policies" contained in a department manual or set of general orders but also unit manuals, standard operating procedures, organizational charts, department memoranda, and possibly even training materials or guides, to the extent that they "implement" an agency's policy choices. If police departments were required to get public input on every single document that the agency produced, they likely would have time for little else - or may simply decide to put fewer things in writing.

178 This is because sometimes an internal agency rule or guidance document may be phrased in such a way that it functions, in practice, like a binding rule. See Anthony, supra note 94, at 1315.

179 Friedman \& Ponomarenko, supra note 10, at 1857.

${ }^{180} \mathrm{Id}$.

181 See, e.g., Texas v. United States, 809 F.3d 134 (2015), aff'd by an equally divided court, $136 \mathrm{~S}$. Ct. 2271 (2016) (per curiam); see also Barkow, supra note 25, at 1156-57. Professor Christopher Slobogin also has argued that police rules that implement suspicionless search and seizure programs ought to be deemed "legislative" rules, though this would require courts to depart pretty substantially from existing law. Compare Slobogin, Policing As Administration, supra note 9, at 96 ("Because . . . panvasive searches and seizures are policy-driven, group-based, and suspicionless, they are legislative in nature."), with U.S. Dep't of Labor v. Kast Metals Corp., 744 F.2d 1145, 1153-56 (5th Cir. 1984) (finding that agency rule concerning suspicionless inspections of regulated industries was not a "legislative rule" within the meaning of the APA). And in any event, these two areas cover only a narrow swath of police conduct.

1825 U.S.C. $\S 551(4)$ (2012). 
The APA largely sidesteps this difficulty by calling everything a rule, but then defining a narrow class of rules that must be adopted through rulemaking procedures. ${ }^{183}$ Because "general statements of policy" and rules about "agency organization, procedure, or practice" are exempt from rulemaking requirements, courts can avoid deciding whether a department training manual or an internal office memorandum is in fact a "rule."184

In the policing context, there are a number of approaches that legislators could take to do the same, but each has its problems. Legislators could, for example, limit rulemaking to those policies and procedures that appear in a department's policy manual or in its general orders. This would be an easy standard to administer but would be both over- and underinclusive. A department's official policy manual contains dozens of administrative policies that likely are of little interest to the public. These include policies on uniform regulations, telephone protocols, grants management, and building security. ${ }^{185}$ On the other hand, the public may have a great deal of interest in knowing more about how officers are trained about when to use force - a topic that department manuals rarely address. ${ }^{186}$ And of course such a requirement would create a powerful incentive to keep certain directives out of the policy manual entirely.

Legislators could - once again — enumerate the topics of concern. But in order to do so, they would need to describe not only the policies that ought to be subject to rulemaking but also the sorts of changes to those policies that would trigger rulemaking obligations. Should an agency be required to go through rulemaking to make any small change to a use of force policy? Perhaps. But what about changing the force reporting structure, or amending a form that officers must use, or tweaking the training curriculum in some way?

Legislators could try instead to adopt a general standard to describe the sorts of policies on which the public would need to weigh in. In Democratic Policing, we pointed to a number of general standards that state courts have used to describe the sorts of questions on which rules or rulemaking might be required. ${ }^{187}$ A department could, for example, be required to get public input whenever it adopts or revises a policy that deals with "broad policy

\footnotetext{
$183 I d . \S 553(\mathrm{~b})(3)(\mathrm{A})$.

${ }^{184} \mathrm{Id}$.

185 See, e.g., AUSTIN POLICE DEPARTMENT supra note 135, at 469, 718, 727, 739 (2017).

186 See, e.g., id. at 630-36 (noting in places that training is required to perform certain functions, but not providing any information about what that training must include).

187 Friedman \& Ponomarenko, supra note 10, at 1882-83.
} 
issues that affect the public at large" or touches on "important areas of social concern." 188

As is true of all ambiguous standards, however, there is likely to be a great deal of uncertainty, at least initially, about when rulemaking is in fact required. One could argue, for example, that any change to a use of force investigation process has the potential to affect the public because it can increase or decrease the likelihood with which officers use force. But one could argue just as easily that minor changes to internal procedures should be exempt because the overall expectation about when officers may use force remains the same.

In short, it certainly would be possible to come up with a plausible rulemaking requirement that captures at least some of the policy issues that have drawn public scrutiny. But doing so would raise a host of challenges that rulemaking proponents have yet to meaningfully confront.

\section{Relying on Rulemaking to Effect Policy Change}

Even assuming that all of the problems discussed above could be solved, the last — and perhaps most pressing — question is the degree to which police rulemaking can be expected to foster greater political accountability and effect real policy change. Although one goal of police rulemaking is simply to get the department itself to be more deliberate and thoughtful about its own policy choices, the driving objective for many rulemaking proponents is to fix policing by giving the public a greater say in how it is policed. ${ }^{189}$ The concern is to what extent rulemaking, or anything like it, can be expected to do that.

As Part I notes, to the extent that scholars have questioned the feasibility of public rulemaking, they have argued that the problem is that rulemaking is not democratic enough - and in turn, have suggested various ways to make rulemaking more inclusive and accessible.

This Section asks a more fundamental question: to what extent can one hope to improve policing by insisting that departments ask for periodic input on policing rules, no matter how democratically that input is obtained?

In making the case for rulemaking, policing scholars have tended to reduce the rulemaking process to a series of referendum-style questions on which it is easy to imagine the public weighing in, and by offering up their views, potentially changing what the police do. Many of these "rulemaking questions" have been about the adoption of new technology: whether to

\footnotetext{
${ }^{188}$ Id. at 1883 (quoting Crema v. N.J. Dep’t of Envtl. Prot., 463 A.2d 910, 917 (N.J. 1983)).

189 See, e.g., Friedman \& Ponomarenko, supra note 10, at 1893-94; Livingston, supra note 7, at 65358; Slobogin, supra note 11, at 996-97.
} 
permit the use of CCTV cameras in a particular neighborhood, for example, or whether a department should be permitted to acquire body cameras or drones. ${ }^{190}$ Others have envisioned public processes around narrow questions relating to use of force, such as whether officers should be required to deescalate potentially violent encounters before resorting to force. ${ }^{191}$ In Democratic Policing, we argued that the public should get to decide whether agencies use drunk-driving checkpoints and whether SWAT teams may be used to effectuate misdemeanor arrests. ${ }^{192}$ Professor Livingston suggested that police could invite residents to provide feedback on whether to permit rollerblading or biking in a particular city park. ${ }^{193}$

All of these questions involve policy matters on which members of the public are likely to have strong views that may be different from those of the police. Acting on their own, police officials might be inclined to get the drone or to permit more expansive use of SWAT. If forced to justify their decisions to a skeptical public, however, they may decide to pursue a different course.

In practice, however, most of the areas in which police rulemaking is needed cannot easily be reduced to these sorts of referendum moments. First, policing outcomes typically are shaped by many overlapping rules. When it comes to use of force, for example, there are rules for when force may be used, how it must be reported, and how it is investigated and reviewed. Agencies also have policies around the handling of complaints and the imposition of discipline. Each of these policies may be many pages in length and scattered across multiple documents. ${ }^{194}$ Use of force outcomes, in short, are the product of a system - one in which the agency's core use of force policy is just one part.

The systemic character of police policymaking has a number of important implications for the viability of democratic rulemaking. One significant limitation of rulemaking procedures is that they are designed primarily to regulate discrete changes to the status quo. Rulemaking requirements typically kick in when an agency proposes a new rule, a revision to an existing regulation, or a novel interpretation of an earlier

\footnotetext{
190 See, e.g., Crump, supra note 11, at 1605-15; Friedman \& Ponomarenko, supra note 10, at 1853; Slobogin, supra note 11, at 996-97.

191 See, e.g., Samuel Walker, Governing the American Police: Wrestling with the Problems of Democracy, 2016 U. CHI. LEGAL F. 615, 657 (2016) (pointing to emphasis on de-escalation in community discussion over use of force in Seattle)

192 Friedman \& Ponomarenko, supra note 10, at 1846, 1848.

193 Livingston, supra note 7, at 646.

194 See, e.g., BALTIMORE DOJ REPORT, supra note 30, at 98 (describing the Baltimore Police Department's policies regarding the use, reporting, and investigation of force as "scattered across multiple documents, making it difficult for officers to synthesize their guidance").
} 
provision. ${ }^{195}$ And this proposed change is what the public is invited to comment on. Traditional rulemaking is not an invitation to rethink an entire regulatory scheme from top to bottom.

For certain areas of policing, this is not necessarily an impediment to meaningful public input. When it comes to surveillance technology, for example, change is indeed what the public often cares about. ${ }^{196}$ The primary concern is that policing agencies will acquire new tools that substantially increase the government's surveillance capacity, or put existing tools to new uses that may generate additional privacy or other costs. ${ }^{197}$ Even if the entire surveillance system is not up for debate in every rulemaking procedure, insisting that agencies get public input on discrete changes to surveillance policies and practices can help ensure that things do not get too out of hand.

But in other policing contexts, it is much harder to imagine that the public can substantially affect outcomes by commenting on discrete changes to police rules. Consider again the use of force. One certainly can imagine specific changes that a department could propose that would benefit from public scrutiny-acquiring new weapons or equipment, for example, or raising the bar for accepting complaints. But by and large, change is not the problem. The problem is, and has for decades been, with the status quo. The operative question is not whether any given change is a good or a bad one. Rather, the question is which of the department's many policies need to change, and in what ways, in order to reduce the amount of force that officers use. Rulemaking proponents have never been clear on which entity, either inside or outside the department, is expected to play that diagnostic role.

This difficulty is compounded by the fact that when it comes to weighing in on policing policies, the public is at an informational disadvantage. In the traditional agency context, regulated entities have a great deal of information about how proposed agency rules will affect them because they are the ones who will have to comply. ${ }^{198}$ Indeed, one justification for notice-and-comment rulemaking is that private parties may have more information than the agency itself. ${ }^{199}$

In the policing context, the public may lack the information it needs to participate fully. To be sure, community members unequivocally have

\footnotetext{
195 See 5 U.S.C. § 551(5) (2012) (defining "rulemaking" as the "agency process for formulating, amending, or repealing a rule").

196 See Crump, supra note 11, at 1597-98 (citing concerns about procurement of new technologies).

197 See id. at $1643-46$.

198 See Richard B. Stewart, The Reformation of American Administrative Law, 88 HARV. L REV. 1669, 1714-15 (1975).

199 Id. at 1713-14 ("[T]he information upon which the agency must ultimately base its decision must come to a large degree from the groups being regulated.").
} 
valuable insight into how policing practices affect them. But they may not always be in a position to assess, from the outside, how police rules will affect the behavior of the police. It may be readily apparent from the outside that officers routinely use excessive force and that they rarely are punished as a result. But it may not always be clear which rules or practices within the department are contributing to this result — especially if the public has little to go on except the text of the rules themselves.

This is particularly true when it comes to rules that regulate internal processes, such as officer discipline. As dozens of Justice Department investigations of local departments make clear, disciplinary systems can fail in any number of ways. ${ }^{200}$ And many of these failures are hard to detect by focusing solely on the substance of policing agency rules. In Chicago, for example, department policy required that disciplinary findings be reviewed up the chain of command. ${ }^{201}$ On paper, this might seem like a reasonable mechanism to ensure that complaints are investigated thoroughly and fairly. ${ }^{202}$ But in Chicago, careful review of agency files made clear that in practice, the requirement "create[d] needless opportunity to undermine accountability" and let officers off the hook. ${ }^{203}$ This sort of information typically would not accompany a request for public comment. But without that information, it is much harder for the public to assess whether the rule is a good one.

The more complex an area of policy, the harder it is to envision ordinary residents and their elected representatives playing a meaningful role in driving policy change - at least not without substantial help. The information asymmetry discussed above is a problem even for experts, such as lawyers, technologists, or former police personnel. This problem is greater still if the goal of rulemaking-type procedures is to empower the broader public to weigh in. In Cleveland, the federal monitoring team spent months preparing videos, fact sheets, and discussion guides in order to facilitate informed discussion on the core aspects of the department's proposed new use of force

200 In New Orleans, for example, the DOJ estimated that officers reported less than a quarter of all use of force incidents - and maybe as few as one in ten. NEW ORLEANS DOJ REPORT, supra note 30, at 14. In Cleveland, "inadequate reports and investigations were approved all the way up the chain of command." CLEVELAND DOJ REPORT, supra note 30, at 33. In Baltimore, interviews with officers involved in deadly force incidents often lasted no more than "ten or fifteen minutes, with some ending after five minutes." BALTIMORE DOJ REPORT, supra note 30, at 108.

201 CHICAGO DOJ REPORT, supra note 30, at 82.

202 After all, commanders also are required to review use of force reports - and their failure to do so thoroughly has been cited in Justice Department investigations as a factor that contributes to excessive force. See, e.g., id. at 44-45.

203 Id. at 82. 
policy. ${ }^{204}$ And of course these materials themselves were based on the results of a lengthy justice department investigation and a months-long policy revision process. ${ }^{205}$ Armed with this information, community members provided valuable comments on certain aspects of the policy, particularly around de-escalation and dealing with youth. ${ }^{206}$ Even still, the public discussion touched on a fraction of the changes that ultimately were made as part of the court-ordered reforms. ${ }^{207}$ It is hard to imagine that any of this would have happened had the Cleveland Division of Police simply been required to obtain public input on proposed changes to department rules.

Although the focus of this Section has been primarily on the use of force, similar concerns apply to a variety of policing matters. Residents may be able to observe that officers are slow to respond when called or that crimes routinely go unsolved. But from the outside it is much harder to assess why that is happening - or to know whether a proposed change to a department policy is likely to make the problem better or worse (or if it is even germane). In New Orleans, for example, the Justice Department found that a key contributing factor to the poor quality of police services was the department's lax secondary employment policy, which skewed the distribution of policing resources across neighborhoods and altered officer incentives in pernicious ways. ${ }^{208}$ On its face, however, a "secondary employment" or "paid detail" policy is unlikely to be one that the public would recognize as a core area of concern. ${ }^{209}$ Indeed, as Professor Seth

204 Motion Recommending Approval of Revised Use of Force Policies of the Cleveland Division of Police at Exhibit G, United States v. Cleveland, No. 1:15-CV-01046 (N.D. Ohio Nov. 16, 2016). (Disclosure: The Policing Project at NYU Law, where I am the Deputy Director, supported the monitoring team in these efforts, and I personally drafted many of these materials.)

205 Cleveland DOJ RePORT, supra note 30, at 9-12; see Motion Recommending Approval of Revised Use of Force Policies of the Cleveland Division of Police at Exhibit G, United States v. Cleveland, No. 1:15-CV-01046 (N.D. Ohio Nov. 16, 2016).

206 Motion Recommending Approval of Revised Use of Force Policies of the Cleveland Division of Police at Exhibit G, United States v. Cleveland, No. 1:15-CV-01046 (N.D. Ohio Nov. 16, 2016).

207 The consent decree alone devoted eighty-four paragraphs to specific changes that needed to be made to use of force policies and practices - and many more were added in negotiations with the monitoring team.

208 NEW ORLEANS DOJ REPORT, supra note 30, at 71.

209 In the decade before the Justice Department investigation, the Times-Picayune published just a handful of articles about abuses of the paid detail system, each of which focused exclusively on a few officers accused of committing payroll fraud by working paid details during their shifts. None of the articles alluded to any of the broader concerns that the Justice Department ultimately revealed. See Susan Finch, N.O. Cop, Acquitted of Fraud, Returns to Work, TimEs-PiCAYUnE, Sept. 12, 2003, at 1; Brendan McCarthy, Cops Accused of Fraud, Again, Times-Picayune, Nov. 24, 2009, at A1; Brendan McCarthy, NOPD Detectives Charged with Pay Fraud, TimEs-PICAYUne, Apr. 16, 2010, at A1. 
Stoughton points out, even policing scholars had given the matter little heed. ${ }^{210}$

Finally, even if one could design a rulemaking process that reduced police policymaking down to the sorts of digestible questions with which this Section began, there still would be a real concern about participation fatigue. If police were to engage in rulemaking around all of the issues that proponents have pointed to- from the enforcement of noise ordinances and bicycle regulations, to new technologies and tactics, to use of force training and officer discipline - how often would the public be asked to weigh in? And to what extent would those who are able to participate regularly represent the views of the broader public affected by the decisions made? This last concern dovetails with the various line-drawing questions raised earlier in this Part. The broader the scope of a proposed rulemaking regime, the more difficult it is to make rulemaking accessible to members of the public who are most heavily impacted by policing rules. The narrower its reach, the less likely it is that the rules that are brought up for public debate will actually end up changing the practices that the public finds most troubling.

Although there are many reasons why we might want policing agencies to adopt rules with some opportunity for public input, there are serious reasons to doubt that rulemaking is a viable strategy for governing policing across a variety of policy domains. Certain kinds of policing decisionsparticularly around new surveillance technologies - may fit reasonably well within the traditional rulemaking paradigm. But many others, for one reason or another, will not. For enforcement discretion, the primary obstacle is that policing agencies have few incentives to adopt guidelines and rules, and it may not be possible to adopt a workable standard that requires them to do so. For use of force, the concern is quite different: given the many policies that influence use of force outcomes and the difficulty of assessing shortcomings from the outside, rulemaking-type procedures may not be the best mechanism for driving policy change or for giving voice to those who are most affected by what police do. To be clear, even in these contexts, rulemaking undoubtedly has some role to play. But it is unlikely, on its own, to bring about sufficient change.

210 Seth W. Stoughton, Moonlighting: The Private Employment of Off-Duty Officers, 2017 U. ILL. L. REv. 1847, 1850. Professor Monica Bell also has since written about the problem of secondary employment, pointing, as this article does, to the Justice Department's New Orleans Report. Bell, supra note 54 , at 2134-36. 


\section{Governing Policing Through AgEnCy DESIGN}

Although Part II sets out good reasons to doubt whether public rulemaking can fix policing, it also underscores that the problem of policing is, fundamentally, a problem of governance. The fact that policing agencies lack the incentive to adopt the sorts of rules that would make policing less harmful and more effective is an obstacle to rulemaking - but it also is a problem that itself needs to be solved. Similarly, although it may be unrealistic to expect the public to get into the nitty-gritty of police systems and rules, it remains true that police department policies incorporate important value judgments that should not be left for police officials to resolve on their own. If rulemaking is not the right model for addressing the governance shortfall, that shortfall must be addressed in some other way.

This Part offers a preliminary sketch of what a more comprehensive set of reforms might entail. It first argues that the various problems with rulemaking identified in Part II point strongly in favor of creating external regulatory structures to help govern the police, such as police commissions or inspectors general. These entities, which I call "regulatory intermediaries," could help shift the incentive structure that discourages police rulemaking, provide more systemic oversight over police policies and practices, and even facilitate broader public input and debate.

Of course, with 18,000 police departments, these sorts of regulatory structures may not be a viable solution to the problems of policing writ large. And in particular, they may not work outside of larger jurisdictions. For this reason, this Part concludes by suggesting that states could play a greater role in governing local policing, both by regulating certain practices directly and by mandating data collection that could reinforce existing local political controls.

\section{A. Regulatory Intermediaries}

Although policing scholars have largely equated administrative law with notice-and-comment rulemaking, a growing number of administrative law scholars have begun to look past rulemaking and focus more broadly on questions of institutional design. Importantly, they have done so in response to problems that look a lot like the sorts of problems that plague policing, including enforcement discretion, internal compliance, resource allocation, and the like. ${ }^{211}$

One of the core insights of the agency design literature is that sometimes the agency itself needs a regulator-to improve the quality of agency deliberations, to facilitate greater internal and external

211 See supra note 25 and accompanying text (collecting examples from this line of scholarship). 
accountability, or to ensure that agencies give certain values greater weight. ${ }^{212}$ Agency regulators, or what this Article calls "regulatory intermediaries," can further these goals in a number of ways. They can generate information about agency practices in order to make those practices more transparent to elected officials and the public at large. ${ }^{213}$ They can serve as a point of contact for groups that typically would not have pull with agency staff. ${ }^{214}$ They can advocate directly for certain values that otherwise might be ignored. ${ }^{215}$ And they can help tackle problems that might not be amenable to being governed through ex ante policies or rules. ${ }^{216}$

Across executive government, "regulatory intermediaries" take on a variety of forms. Dozens of federal agencies, including the Central Intelligence Agency and the Department of Justice, have inspectors general who review agency policies and practices and make recommendations about changes that ought to be made. ${ }^{217}$ A number of other agencies have offices within the agency created specifically to advocate for certain values or norms. ${ }^{218}$ Independent agencies typically are governed by multimember boards and commissions, which, as Professor Barkow notes, creates a "builtin monitoring system for interests on both sides" that can help to ensure that agency decisions accommodate a more diverse range of views. ${ }^{219}$ Sister agencies sometimes also are authorized to regulate each other. For example,

212 See generally Eric Biber, Too Many Things to Do: How to Deal with the Dysfunctions of MultipleGoal Agencies, 33 HARV. EnvTL. L. REV. 1, 41-46 (2009) ("Congress could use additional federal agencies to monitor and observe the activities [of another agency] to ensure that it is relatively faithful to the principal's instructions."); Metzger, supra note 25, at 437-47 (arguing that "internal separation of powers" structures are essential for maintaining effective external controls).

213 See, e.g., Renan, supra note 26, at 1121.

214 See Metzger, supra note 25, at 429-30; Schlanger, supra note 26, at 100-01 (discussing "outreach" and "document generating" function that internal agency regulators—what she calls "Offices of Goodness" - can play).

215 See Schlanger, supra note 26, at 61 (describing Offices of Goodness as "value-infused"meaning they are created "to further a particular value that is not otherwise primary for the agency in which they sit").

216 See Cuéllar, Auditing Executive Discretion, supra note 151 (arguing in favor of auditing as a way to address discretionary enforcement decisions).

217 For a full list of Federal Inspectors General, see Inspectors General Directory, CounCIL OF INSPECTORS GEN. ON INTEGRITY \& EFFICIENCY, https://www.ignet.gov/content/inspectors-generaldirectory [https://perma.cc/9RQ5-N2EJ].

218 Schlanger has dubbed these "Offices of Goodness." Schlanger, supra note 26, at 55. The Department of Homeland Security, for example, has an Office for Civil Rights and Civil Liberties tasked with ensuring "that the protection of civil rights and civil liberties is appropriately incorporated into Department programs and activities." Id. at 62; Office for Civil Rights and Civil Liberties, Dep't Homeland Sec., https://www.dhs.gov/office-civil-rights-and-civil-liberties [https://perma.cc/EYG7LJLQ].

219 Rachel E. Barkow, Insulating Agencies: Avoiding Capture Through Institutional Design, 89 TEX. L. REV. 15, 41 (2010); see also Gersen, supra note 25, at 696 (making a similar point). 
a number of statutes require federal agencies to consult with either the EPA or the Fish and Wildlife Service before undertaking certain actions that could impact the environment. ${ }^{220}$ Indeed, as Professor Neal Katyal points out, legislatures often are more willing to create these sorts of regulatory structures than they are to make tough policy choices themselves. ${ }^{221}$

These regulatory structures exist at the local level as well. School superintendents typically answer to elected or appointed boards, as do many other local agencies, including health departments and zoning administrations. ${ }^{222}$ Cities also rely on a variety of structures to hold agencies accountable, including inspectors general, ombudsmen, and public advocates. ${ }^{223}$ In New York City alone, several dozen municipal agencies have dedicated inspectors general with varying degrees of authority over agency affairs. ${ }^{224}$

Although regulatory intermediaries also exist around policing, they are comparatively rare. ${ }^{225} \mathrm{~A}$ handful of police departments in major cities, including Detroit, Milwaukee, Los Angeles, and San Francisco, are governed (more or less) by civilian police commissions with final authority to set policy for the police. ${ }^{226} \mathrm{~A}$ larger number of other departments have police auditors or inspectors general who have authority to review department policies and practices and recommend policy changes. ${ }^{227}$ Far more common around policing are Civilian Review Boards, which either investigate allegations of police misconduct or review completed investigations after the

220 See, e.g., National Environmental Policy Act, 42 U.S.C. $\$ 7609$ (2012); Endangered Species Act, 16 U.S.C. $\$ 1536$ (2012).

221 Katyal, supra note 25, at 2323 (noting that "broad design choices are easier to impose by fiat than are specific policies").

222 See Paul A. Diller, Local Health Agencies, the Bloomberg Soda Rule, and the Ghost of Woodrow Wilson, 40 FORDHAM URB. L.J. 1859, 1877 (2013) ("Usually, the 'board' is the governing body of the 'department,' with the authority to adopt rules that department officials execute."); Nadav Shoked, An American Oddity: The Law, History, and Toll of the School District, 111 Nw. U. L. REV. 945, 955-57 (2017) (describing school districts as "political subdivisions" that have the power to "appoint teachers and prescribe salaries, select courses and textbooks, and assign students to specific schools").

223 See Mark Green \& Laurel W. Eisner, The Public Advocate for New York City: An Analysis of the Country's Only Elected Ombudsman, 42 N.Y. L. SCH. L. REV. 1093, 1117 n.108 (1998) (listing ombudsmen); Directory of State and Local Inspector General Agencies, Assoc. OF INSPECTORS GENERAL, http://inspectorsgeneral.org/useful-links/directory-of-state-and-local-government-oversightagencies [https://perma.cc/57R4-NLX2] (providing a partial list of inspectors general).

224 List of DOI Inspectors General, NEW YORK CITY'S INSPECTOR GENERAL, https://www1.nyc.gov/site/doi/contact/contact-inspectors-general.page [https://perma.cc/3YLC-EFUL].

225 For a general overview of various governance structures, see SAMUEL E. WALKER \& CAROL A. ArchBold, The New World of POlice ACCOUNTABILITY (3d ed. rev. 2019).

226 L.A., Cal., Charter art. 5, § 571 (2019); Detroit, Mich., Charter, art. 7, ch. 8, §§ 7-802803 (2012); S.F., Cal., Charter, art. 4, § 4.109 (2018); MilWAuKeE, Wis., ch. 314, § 1 (2019).

227 Joseph De ANGElis ET AL., Civilian Oversight of LAW ENFORCEMENT: Assessing THE EVIDENCE 32 (2016) (listing several cities with auditors or inspectors general). 
fact. ${ }^{228}$ But these "back-end" bodies, which focus almost exclusively on individual instances of misconduct, have done little to address the broader governance shortfall around how police decisions are made. ${ }^{229}$

This is beginning to change. In recent years, a number of major citiesincluding Seattle, Chicago, and New York-have created powerful new offices of the Inspector General to oversee their police departments. ${ }^{230}$ Seattle also created a permanent Community Police Commission to work alongside the Inspector General to review police department policies and practices and make recommendations. ${ }^{231}$ Several other cities are considering proposals to do the same. ${ }^{232}$

The problem, as others have pointed out, is that in setting up these new structures, jurisdictions must resolve a number of difficult questions without much guidance.233 What powers, for example, should a regulatory intermediary have? Is it essential for the entity to have power to set policy, or is it sufficient (or even preferable) for the body to make recommendations without having the final say? Should police departments, like schools, be governed by multi-member commissions, or would it be better to set up more streamlined structures to strengthen existing political controls? Should the

228 See Police Oversight by Jurisdiction (USA), NATIONAL ASSOCIATION FOR CiviLIAN OvERSIGHT OF LAW ENFORCEMENT, https://www.nacole.org/police_oversight_by_jurisdiction_usa [https://perma.cc/85AL-9YTW] (listing cities with civilian oversight entities, most of which are CRBs); Martin Kaste, Police Are Learning To Accept Civilian Oversight, But Distrust Lingers, NPR (Feb. 21, 2015, 10:18 AM), https://www.npr.org/2015/02/21/387770044/police-are-learning-to-accept-civilianoversight-but-distrust-lingers [https://perma.cc/3GDQ-FJ77] (noting that there are more than 200 such entities).

229 See Friedman \& Ponomarenko, supra note 10, at 1877 (distinguishing between "front-end" and "back-end" accountability); Debra Livingston, The Unfulfilled Promise of Citizen Review, 1 Оніо ST. J. CRIM. L. 653, 661 (2003) (noting the limits of CRBs, including that CRBs tend to focus too heavily on "rule enforcement" as opposed to more systematic review); Miller, supra note 11, at 547 (drawing a similar distinction); Joanna C. Schwartz, Who Can Police the Police?, 2016 U. CHI. LEGAL F. 437, 46667 (2016) (noting the limited success of such bodies).

${ }^{230}$ New York City created the Office of the Inspector General for the NYPD in 2014. N.Y.C., N.Y., LOCAL LAw, No. 70 (2013), https://www1.nyc.gov/assets/doi/oignypd/local-law/Local-Law-70.pdf [https://perma.cc/W5KT-BL5S]. Chicago revamped its regulatory structure, adding a Deputy Inspector General for Public Safety, in 2016. CHI., IL., MuniCIPAL CODE § 2-56-205 (2016). Seattle created an Office of Inspector General for Public Safety in 2017, SEATTLE, WASH., ORDinANCE 125315 (2017).

231 Seattle, Wash., ORdinanCE 125315 (2017).

232 See, e.g., Sarah Schulte, Group Proposes Civilian Commission to Oversee Chicago Police, ABC 7: CHI. (Mar. 13, 2018), https://abc7chicago.com/group-proposes-civilian-commission-to-overseechicago-police/3211657 [https://perma.cc/DZ85-QZMV].

${ }^{233}$ See, e.g., DE ANGELIS, supra note 227, at 10-12 (2016) (noting the dearth of research on the effectiveness of civilian oversight); Jessica Lee, Many Questions, Few Answers, MinNEAPOLIS POST (Aug. 1, 2018), https://www.minnpost.com/politics-policy/2018/08/many-questions-few-answersminneapolis-council-takes-proposal-change-police [https://perma.cc/2ERZ-6RKY] (lamenting the fact that "very little research exists on the effectiveness of distributing the power of police departments among multiple arms of government"). 
regulatory body review policing policies and practices from a distance, or should staff members be more integrated into the department structure so as to weigh in on decisions as they come up?

Over the years, a number of scholars have urged greater attention to these sorts of questions - but with the exception of some important work by Professors Samuel Walker and Joanna Schwartz, there have been few attempts to answer them. ${ }^{234}$ Notably lacking is a clear theory on precisely what is missing around policing governance - and by extension, the institutional structures that are necessary to effectively govern the police. ${ }^{235}$

The remainder of this Section sets out a preliminary framework for resolving these questions, which follows naturally both from the problems with policing and the obstacles to rulemaking identified in Parts I and II.

\section{Information}

One of the main obstacles to public rulemaking - and to public oversight of policing more generally - is the difficulty of identifying shortfalls in department practices by relying solely on the text of department rules. ${ }^{236}$ Given the systemic character of many policing outcomes, a regulatory intermediary must have the authority to review police department records and conduct the sorts of top-to-bottom investigations that are necessary to identify where the problems are, and the changes that should be made to address them.

In short, some sort of auditing function is essential - the ability to review agency records, speak with department officials, and figure out where things are going wrong and why. Generating this sort of information would serve two important functions. It would improve the quality of the regulatory intermediary's own policy recommendations. And just as importantly, it would help facilitate more informed public debate around policing by making the problems of policing more transparent to elected officials and to the public at large.

Yet this is precisely the function that often is lacking among existing police oversight models. As discussed above, civilian review boards focus

234 See WALKER, supra note 225 (discussing various institutional controls); Rachel A. Harmon, The Problem of Policing, 110 Mich. L. REV. 761, 764 (2012) (urging greater attention to institutions that can help effectively regulate the police); Schwartz, supra note 229, at 438 (noting that the question of "who is best situated to advance [police] reforms ... has received less attention" and suggesting a preliminary framework for analyzing the strength of various entities both in and out of government); David Alan Sklansky, Police and Democracy, 103 Mich. L. REV. 1699, 1802 (2005) (arguing for more scholarly attention to "institutional mechanisms traditionally relied upon for democratic control of the police — city councils, mayors' offices, and, more recently, civilian oversight agencies.").

235 Harmon, supra note 234, at 764; Sklansky, supra note 234, at 1802.

236 See supra Section II.D. 
almost exclusively on individual instances of misconduct — and although they sometimes have the authority to make broader policy recommendations, they rarely are in a position to generate the information necessary to exercise it effectively. Many review boards are made up entirely of unpaid volunteers, without a professional staff and without unfettered access to department files. The same often is true of police commissions, including commissions with formal authority to set policy for the department and hire or fire the chief of police. ${ }^{237}$ Without this authority and capacity, however, these boards are only marginally better off than the general public or elected officials in regulating the police.

\section{Incentives}

Much of Part II focused on problem of incentives - and in particular, the lack of incentive on the part of policing agencies to adopt the sorts of policies and practices that could make policing more equitable and reduce some of its collateral costs. The problem is hardly unique to policing agencies: as Professor Margo Schlanger notes, "[i]nducing governmental organizations to do the right thing is the central problem of public administration," particularly "when 'the right thing' means executing not only a primary mission but also constraints on that mission." 238 The Forest Service, for example, has at times privileged timber production over the competing goal of conservation. ${ }^{239}$ The Department of Housing and Urban Development has at times promoted new housing construction while downplaying environmental concerns. ${ }^{240}$ In the policing context, the challenge has been to ensure that policing agencies pursue their law enforcement mission in a manner that respects constitutional rights, minimizes undue intrusions on liberty and privacy, and complies with equality norms.

237 See, e.g., Richard Jerome, Police Assessment Resource Ctr., Promoting Police Accountability in Milwaukee: Strengthening the Fire and Police Commission 1-5 (2006) (noting that despite its wide-ranging formal powers, the commission has been rightly perceived to be "weak and ineffective" due in large part to the lack of an independent monitor or auditor with the staff necessary to conduct thorough policy reviews); REPORT OF THE RAMPART INDEPENDENT REVIEW PANEL 4-6 (2000) (finding that "[h]istorically, the Commission has not exercised the degree of control over the Department that one would expect given the Charter's broad grant of power to the Commission" because it lacked the capacity to undertake systematic review of department policies and practices).

238 Schlanger, supra note 26, at 54; see also JAMES Q. WILSON, BUREAUCRACY: WHAT GOVERNMENT AGENCIES Do AND WHY THEY Do IT 371 (1989) (noting that "those tasks that are not part of the core mission will need special protection").

239 Barkow, supra note 219, at 50.

240 See Nicholas Bagley \& Richard L. Revesz, Centralized Oversight of the Regulatory State, 106 CoLuM. L. REV. 1260, 1301 (2006) ("HUD zealously pursued its housing goals while giving short shrift to the environmental consequences."). 
Regulatory intermediaries could help address the incentives problem in two ways. First, an entity that sits at some remove from a police department and yet is charged specifically with regulating its policies and practices will likely have the incentive to supervise policing practices in ways that the department itself does not. ${ }^{241}$ Individuals who step into an oversight role typically come from different professional backgrounds than do law enforcement professionals. ${ }^{242}$ These individuals may feel themselves beholden to a different political constituency and thus be more sympathetic to certain values than either mayors or chiefs. ${ }^{243}$ In New York, for example, the NYPD's Inspector General has focused on a number of policy issues on which police self-governance has typically fallen short, including surveillance of political protests, overenforcement of quality of life offenses, and the handling of civilian complaints. ${ }^{244}$ In Chicago, the newly appointed Deputy Inspector General for Public Safety promised to begin his task by evaluating the department's policies and practices around secondary employment, gang databases, and the use of school resource officers, among others. ${ }^{245}$

Second, by generating information about existing policy shortfalls, a regulatory intermediary could help nudge policing agencies to address problems that they otherwise might ignore. They can alert senior department officials to problems that they simply were not aware of. And they can generate information that advocates and plaintiffs can then use to push for change. In 2018, for example, the NYPD Inspector General issued a scathing report regarding the NYPD's mishandling and underenforcement of sexual

\footnotetext{
${ }^{241}$ Katyal, supra note 25, at 2324 (noting that "[w]here you stand is a function of where you sit").

242 The NYPD Inspector General Philip K. Eure, for example, spent a decade at the Civil Rights Division within the Department of Justice, and then another fourteen years as the head of the civilian complaints bureau in Washington, D.C. See Inspector General's Biography, DEP'T OF INVESTIGATION, N.Y.C., https://www1.nyc.gov/site/oignypd/about/biography.page [https://perma.cc/RF3W-A4B2].

${ }^{243}$ Schlanger, supra note 26, at 109 (noting that the "natural opponents" of an agency may be the "natural constituents" of an "Office of Goodness").

${ }^{244}$ For a list of reports issued by the NYPD OIG, see IG-NYPD Reports, OFF. INSPECTOR GEN. NYPD, https://www1.nyc.gov/site/oignypd/reports/reports.page [https://perma.cc/MHB5-389Z].

245 Press Release, Office of Inspector Gen., City of Chicago Office of the Deputy Inspector General for Public Safety Releases Initiated Projects List (Mar. 22, 2018), http://chicagoinspectorgeneral.org/ publications-and-press/press-releases/city-of-chicago-office-of-the-deputy-inspector-general-for-publicsafety-releases-initiated-projects-list [https://perma.cc/TDN6-3VFD].
} 
assault cases. ${ }^{246}$ Although the NYPD initially pushed back against the findings, it ultimately made a number of changes in response. ${ }^{247}$

Importantly, regulatory intermediaries could help address the incentives problem while sidestepping some of the difficulties inherent in mandatory rulemaking regimes. In particular, relying on a regulatory intermediary avoids the difficulty of having to specify in advance which policies and practices must be subject to rules or public input. ${ }^{248}$ A regulatory intermediary can review department policies, records, data, and complaints to identify areas in which rules are lacking or flag policy questions on which the public ought to weigh in. Instead of looking to the legislature to specify every possible policing practice that could benefit from having more or better rules, one could look to a regulatory intermediary to assess, on an ongoing basis, which practices in fact would.

The problem, of course, is that regulatory intermediaries are likely to face incentives problems of their own — or they simply may be unable to alter the existing incentives structure enough to effect meaningful change. Indeed, one of the biggest challenges in policing governance is the fact that policing has been as much a problem of democracy as it has been a problem of its absence. Policing often looks the way that it does because those who have the greatest stake in bringing abusive or intrusive practices under control often are the least organized politically to push for change. ${ }^{249}$ Designing a regulatory framework around policing that operates within the existing political structure-while standing sufficiently apart to avoid the political pathologies around police decisionmaking - is no easy task.

Three design choices touch directly on the problem of incentives - but here, the answers are less clear-cut than they are with respect to the information-generating function that a regulatory intermediary must play.

The first question is whether a regulatory intermediary ought to be able to mandate specific policy changes, or simply issue recommendations as to the changes that ought to be made. A small number of police commissions have final policymaking authority. ${ }^{250}$ Other commissions are purely

246 MARK G. PETERs, COMMISSIONER, N.Y.C. DEP'T OF INVESTIGATION's INSPECTOR GEN. FOR NYPD, AN InVESTIGATION OF NYPD's SPECIAL Victims Division-AdUlt SEX CRIMES (2018), https://www1.nyc.gov/assets/doi/reports/pdf/2018/Mar/SVDReport_32718.pdf [https://perma.cc/VLA7-PGQ5].

247 Myles Miller, Shakeup of the NYPD's Special Victims Division After Scathing Report, NY1.COM (Nov. 19, 2018, 10:10 AM), https://www.ny1.com/nyc/all-boroughs/news/2018/11/16/shakeup-of-thenypd-s-special-victims-division-after-scathing-report [https://perma.cc/L9JE-696G].

${ }^{248}$ Cf. supra Section II.C (discussing the challenges of deciding what constitutes a policy or rule requiring public input in the first place).

249 See generally Dripps, supra note 141.

250 See supra note 226 and accompanying text. 
advisory. ${ }^{251}$ Inspectors general (IGs) are authorized only to recommend changes and track compliance - though in Los Angeles, the IG reports to a Police Commission, which does in fact have the authority to insist on policy change. ${ }^{252}$ The question is whether the authority to make recommendations, without the authority to implement them, is enough to prompt meaningful change.

As discussed above, even purely advisory bodies can prompt policymaking in a variety of ways - by making problems more difficult to ignore and by arming advocates with the information they need in order to push for change. The NYPD, for example, has implemented or partially implemented more than half of the recommendations made by the IG in its first three years, including important changes to use of force policies and training. ${ }^{253}$ Yet the recommendations that the NYPD has rejectedparticularly around the disproportionate racial impact of quality of life enforcement - are perhaps indicative of the limits of this model. ${ }^{254}$ At the federal level, inspectors general often have been ignored when they raise issues involving matters about which legislators have decided not to care. ${ }^{255}$

At the same time, there are reasons to doubt whether the power to mandate policy is preferable. Professor Barkow points out, for example, that state sentencing commissions without final policymaking authority have sometimes been more effective than their more powerful counterparts in other states. ${ }^{256}$ Some of the most successful sentencing commissions are ones that operate "as interest group[s] for rational sentencing policy" and not as independent experts who set policy themselves. ${ }^{257}$ Much of this has to do with the fact that legislatures tend to be quite active around sentencing issues and as a result have tended to override sentencing commission decisions with which they disagree. ${ }^{258}$ Although legislatures have traditionally been much less active in the policing space, there still are reasons to think that policymaking bodies could face an uphill battle in the policing context as well. First, given the stakes involved in appointing individuals to policysetting bodies and the political strength of police unions in many jurisdictions, mayors and city council members may face pressure to appoint

251 See, e.g., SEATTLE, WASH., ORDINANCE 125315 (2017).

252 L.A., CAL., CHARTER art. V, § 571(4) (2017).

253 N.Y.C. DEP'T OF INVESTIGATION, OfFICE OF the INSPECTOR Gen. FOR THE NYPD, ThiRD ANNUAL REPORT 28-32 (2017).

${ }^{254}$ Id. at $9-12$.

255 See, e.g., Schlanger, supra note 26, at 89 (pointing out that concerns over a sweeping new federal data collection program simply "didn't catch on").

256 Barkow, Administering Crime, supra note 26, at 799.

${ }^{257}$ Id. at 720.

${ }^{258}$ Id. at 799-800. 
individuals who are less likely to upend the status quo. Commissioners themselves may be reluctant to routinely impose policy on the department by fiat. And as Part II makes clear, police officials up and down the chain of command have lots of mechanisms at their disposal to thwart policy changes with which they disagree. This is an area where more research is needed to better understand how both advisory and policy-setting bodies have fared.

Another important question is whether a regulatory intermediary should be entirely independent from the police department or whether it should be integrated into the agency in some way. One of the concerns with regulatory intermediaries throughout government is that they may become "coopted" or "captured" by the entity that they are tasked with regulating-and thus become less likely to push for change. ${ }^{259}$ As Professor Herbert Simon observed, "[o]ne does not live for months or years in a particular position in an organization, exposed to some streams of communication, shielded from others, without the most profound effects on what one knows, believes, ... and proposes." ${ }^{260}$ Individuals who come into the position with one set of views may find that over time their views substantially evolve. ${ }^{261}$ For this reason, many have argued in favor of creating regulatory bodies that are entirely independent of the agencies that they are expected to regulate.

At the same time, too much distance between the regulator and the regulated can deprive the former of valuable information and potentially reduce its persuasive authority. It also may limit the sorts of decisions on which a regulatory intermediary could weigh in - and by extension, its ability to effect systemic change. Professor Schlanger notes, for example, that one of the advantages of situating a regulatory intermediary within an agency is that officials are able to sit in on meetings and potentially influence agency decisions on an ongoing basis. ${ }^{262}$ Given the fluid nature of police decisionmaking, certain policy choices may be difficult to discern from agency records after the fact. This is another area in which more research is necessary to know which is likely to be the greater concern.

Finally, a third set of questions concerns the manner in which regulatory intermediaries are chosen. The appointments process tends to be the point at which abstract questions of institutional design run into the messy reality of politics. A police commission with all of the resources and authority in the world may still accomplish nothing if the mayor appoints political cronies

\footnotetext{
259 See, e.g., Schlanger, supra note 26, at 112-13.

${ }^{260}$ Herbert A. Simon, Administrative Behavior: A Study of Decision-Making Processes IN ADMINISTRATIVE ORGANIZATIONS 18 (4th ed. 1997); see also Schlanger, supra note 26, at 113.

261 Schlanger, supra note 26 , at 112-16.

262 Id. at 94.
} 
who have little interest in actually governing the police. ${ }^{263}$ Elected boardschosen in low-visibility local elections with a powerful police union presence - may not fare any better. ${ }^{264}$ There are, in short, no easy answers. And some options may be precluded by municipal structure or local custom. Still, it is possible to at least sketch out what the various considerations might be.

To start, the range of viable options likely is quite a bit narrower for IGs than it is for commissions or boards. Inspectors general almost universally are appointed. ${ }^{265}$ Indeed, one of the key features of an inspector general model is thought to be their removal from ordinary politics. ${ }^{266}$

For local commissions and boards, on the other hand, there are fewer constraints on the manner in which members are chosen. The arguments both for and against elected boards in local government are familiar-though much of the debate has taken place in the context of governing public schools. The argument in favor of elections is that they are more "democratic" and give voters an opportunity to hold officials accountable for outcomes within a specific policy domain. ${ }^{267}$ On the other hand, turnout in municipal elections tends to be low to begin with, and many voters do not pick candidates in down-ballot races at all. ${ }^{268}$ Some have expressed concern that elections tend to attract candidates who may see the position as a stepping-stone to higher political office and may lack the qualifications or commitment necessary to do the work. ${ }^{269}$ Finally, there are serious concerns about union influence - perhaps more so in the policing context given the

263 See, e.g., Gene I. MAEROFF, SCHOOL BOARDS IN AMERICA: A FlAwED ExERCISE IN DEMOCRACY 175 (2010) (citing concerns over mayoral appointment in the context of school governance); Walker, supra note 191, at 639 (describing the Los Angeles Police Commission's authority over the police department throughout the twentieth century as "illusory").

264 For criticism of local board elections, see Terry M. Moe, Teacher Unions and School Board Elections, in BESIEGED: SCHOOL BOARDS AND THE Future OF EdUCATION POLITICS 254-57 (William G. Howell ed., 2005).

265 One exception has been the Public Advocate of New York City - an elected ombudsman with broad investigative powers, who also performs a variety of more overtly political functions. But given the fraught politics around policing and criminal justice, discussed below, this does not seem like a particularly viable option if limited primarily to the policing space.

266 See, e.g., MOdEL LEGISLATION FOR THE ESTABLISHMENT OF OFFICES OF INSPECTOR GENERAL, AsSOC. OF INSPECTORS GENERAL (2002), http://inspectorsgeneral.org/files/2011/01/IG-ModelLegislation.pdf [https://perma.cc/SVT7-3RHG] (model statute proposed by the Inspectors General Association, which emphasizes the importance of independence and expertise).

267 MAEROFF, supra note 263, at 192; Kent Willis, Why We Have-and Should Have-Elected School Boards in Virginia, ACLU OF VA. (Oct. 15, 2009), https://acluva.org/en/press-releases/why-we-haveand-should-have-elected-school-boards-virginia [https://perma.cc/G8QD-9WZQ].

268 Rebecca D. Gill, Beyond High Hopes and Unmet Expectations: Judicial Selection Reforms in the States, 96 JUDICATURE 278, 288 (2013) (“Although ballot roll-off in retention elections has declined over time, about a third of voters still fail to vote at the bottom of the ticket.").

269 MAEROFF, supra note 263, at 190. 
degree of divergence between the policy preferences of police union leaders and the concerns of residents in heavily policed communities.

Although there are problems with appointments as well-including some of the same concerns about political ambition and union influencethere may be a variety of strategies for structuring appointment processes in a way that can mitigate them to some degree. In both Chicago and New York, for example, the police IG is appointed by a citywide inspector general who is at some remove from city politics and may have a different set of professional and reputational interests at stake in picking a credible candidate. ${ }^{270}$ Merit selection panels that include a variety of stakeholder representatives are another possible choice. ${ }^{271}$ Even political appointments can be structured at least to some extent-for example, by requiring a commission to include individuals with particular professional backgrounds, such as a public defender or someone from the mental health community. ${ }^{272}$

Ultimately, more research is needed to assess the effectiveness of various models. Still, focusing squarely on the problem of incentives at the very least makes clear the questions that must be resolved - and the potential tradeoffs involved.

\section{Legitimacy and Representation}

Finally, part of what drove rulemaking proponents was the recognition that police policymaking is shot through with value judgments that should not be left to the police to resolve on their own. The same critique, however, could be leveled at a regulatory intermediary as well-particularly if the entity is insulated from the affected communities whose interests it is supposed to represent. What this means is that a regulatory body must either be vested with some degree of representative legitimacy to speak for the broader public, or it must have mechanisms to hear from various stakeholders on a regular basis.

\footnotetext{
270 See CHI., ILL., MunicIPAL CODE § 2-56-220 (2016) (providing for a police IG who is an "attorney with substantial experience in criminal, civil rights, and/or labor law, or corporate and/or governmental investigations" and who is selected by the city Inspector General); Inspector General of the NYPD, DEP'T OF INVESTIGATION $\quad$ N.Y.C., $\quad$ https://www1.nyc.gov/site/doi/offices/oignypd.page [https://perma.cc/5ML5-X9YA] ("The Office of the Inspector General for the NYPD . . is independent of the NYPD and sits within the New York City Department of Investigation.”).

${ }^{271}$ Merit selection panels have been used in a variety of contexts, including around judicial selection. A merit selection panel could itself be comprised of various stakeholders-including, for example, a mix of police officials, local prosecutors and public defenders, and representatives from various affected communities. On merit selection in the judicial context, see, for example, Malia Reddick, Merit Selection: A Review of the Literature, 106 DiCK. L. REV. 729 (2001).

272 See, e.g., Seattle, Wash., ORdinance 125315 (2017) (requiring someone from the civil liberties community and a public defender); Barkow, Administering Crime, supra note 26, at 783 (noting that the North Carolina sentencing commission must include someone who has previously been incarcerated).
} 
This last consideration has a number of important implications for how a regulatory intermediary is structured and staffed. One way that a regulatory entity can incorporate a broader range of perspectives is by including various community stakeholders in its policymaking process. The San Francisco Police Commission, for example, convened a working group of community members and police officials to revise the department's policy on immigration enforcement. ${ }^{273}$ Similarly, in preparing its report on officer interactions with people in mental crisis, the NYPD Inspector General's office "interviewed advocates from mental health organizations and attended public forums to hear perspectives of people living with mental illness ...." ${ }^{274}$ Other entities at both the federal and local level have played a similar function. ${ }^{275}$

There are, however, a number of limitations to this approach. One concern is that it puts the onus on the agency itself to identify both the issues that would benefit from public input and the perspectives that ought to be heard. Another is that this sort of engagement requires staff capacity that existing entities often lack. Although the larger inspectors general offices in cities like Los Angeles and New York have dedicated outreach workers to ensure close collaboration with various stakeholders, auditors or IGs in smaller jurisdictions may have few, if any, staff members at all. ${ }^{276}$ If the goal is to rely on regulatory intermediaries to facilitate public input in police decisionmaking, they must be staffed accordingly to ensure that this occurs.

Another way to ensure some degree of representative legitimacy is to create a multi-member board or commission to work in tandem with an auditor or IG. In Los Angeles, for example, there is both an IG and a civilian Police Commission. The latter acts as a "board of directors" for the police

273 Police Commission, San Francisco Police Department, DGO 5.15 Enforcement of Immigration Laws, https://sfgov.org/policecommission/dgo-515-enforcement-immigration-laws [https://perma.cc/S5V8-D879] (describing the formation of a working group to review the San Francisco Police Department's immigration enforcement practices).

274 MARK G. Peters, COMmissioner, N.Y.C. DEP'T OF InVESTigation's InSPECTOR GEN. OF THE N.Y. POLICE DEP'T, Fourth ANNUAL REPORT 43 (2018).

275 See, e.g., Renan, supra note 26, at 1121 (noting that the Privacy and Civil Liberties Oversight Board has helped make "the myriad administrative rules governing a complex and sprawling surveillance program ... more visible" and also "more accessible" to the public at large); Schlanger, supra note 26, at 100-01; see also Mariano-Florentino Cuéllar, Rethinking Regulatory Democracy, 57 ADMIN L. REV. 411, 490-92 (arguing in favor of creating a federal agency dedicated to facilitating informed public comments from the broader public on key policy issues).

276 See, e.g., OfFice of THE INDEPENDENT Police Auditor, City OF SAN Jose, 2017 IPA YeAR END REPORT, at ii (2018) (listing a staff of five, including four analysts and an administrator); Independent Police Auditor, CITY OF DAVIS, CAL. https://cityofdavis.org/city-hall/police-department /administration/independent-police-auditor/-fsiteid-1 [https://perma.cc/XB8R-R3LG] (describing a parttime Independent Police Auditor position). 
department and also directs the IG's efforts. ${ }^{277}$ Seattle has an IG as well as an advisory Community Police Commission, which can recommend specific policy issues for the Inspector General to pursue. ${ }^{278}$ This approach is not unique to policing. Throughout government, we often look to representative bodies to stand in for the public in making the many decisions that must be made without the benefit of a referendum or a wide-ranging public debate.

The degree to which any board or commission can perform that function depends, of course, on how its members are appointed. In Seattle, commissioners are required by law to reflect a balance of perspectives and views - including individuals who either come from or work directly with communities that traditionally have been heavily impacted by the police. ${ }^{279}$ In Los Angeles, however, the Police Commission has traditionally not been "representative" in the same way. As of 2019, its five-member board included a business leader, a developer, a law professor, a foundation president, and the head of a local nonprofit (the latter two both represent organizations that provide direct services to various impacted communities, including the homeless or LGBT youth). ${ }^{280}$ Although a multi-member commission may still lend greater legitimacy to police decisionmaking than a chief of police or a stand-alone IG, a commission that is structured along the lines of the Los Angeles model may not be able to rely on its "representative" legitimacy alone.

Finally, commissions are not the only government bodies that can represent the broader public in regulating the police. Some jurisdictions, for example, have experimented with vesting greater authority in city councils, either over particular policy issues or over the department as a whole. ${ }^{281}$ And sometimes, city councils have created their own advisory groups to help

${ }^{277}$ L.A., CAL. CHARTER art. 5, $§ 571, \S 573$ (2019) (describing the powers of the commission and IG). On the use of the phrase "board of directors," see Police Commission, LAPD http://www.lapdonline.org/police_commission [https://perma.cc/3M3P-3T34].

278 SEATtLE, WASH., ORDiNANCE 125315 \$ 3.29.300, 3.29.200 (2017) (describing the powers of the commission and IG).

${ }^{279}$ Id. $\$ 3.29 .340$ (2017) (“Commissioners shall be representative of Seattle's diverse population . . including immigrant/refugee communities, and ... African-American, LGBTQ, youth, faith, business, and other communities .... Some shall represent or be knowledgeable of the issues of those who are limited-English speakers, homeless, or who have mental illness and substance abuse disorders.").

${ }^{280}$ See Police Commission, LAPD, http://www.lapdonline.org/police_commission [https://perma.cc/3M3P-3T34] (detailing biographies of the five commissioners); Sandra Figueroa-Villa, LAPD, http://lapdonline.org/police_commission/comm_bio_view/54347 [https://perma.cc/BGZ7-SQE8]; Shane Murphy Goldsmith, LAPD, http://www.lapdonline.org/ police_commission/comm_bio_view/61355 [https://perma.cc/7W4Q-U3SN].

${ }^{281}$ See, e.g., Seattle, Wash., Ordinance 125315 (June 1, 2017); Lee, supra note 233 (describing Minneapolis proposal to give some policymaking authority to a city council). 
inform these decisions. ${ }^{282}$ These sorts of models may be worth exploring as well.

Ultimately, more research clearly is needed to provide jurisdictions with concrete guidance about the regulatory models that are most likely to work. What the preceding Section suggests, however, is that in assessing these models, researchers should focus on the degree to which existing regulatory bodies are able to further three specific goals: (1) generating information about potential shortfalls in department policies and practices; (2) creating the incentives necessary for police departments to address them; and (3) ensuring that key policy decisions are informed by the views of the various stakeholders who are likely to be impacted by the choices made.

\section{B. Rethinking Local Governance of the Police}

Although regulatory intermediaries can play an important role in police governance, they are at best a solution to the problems of urban-and perhaps suburban-policing. It simply may not be feasible for smaller municipalities to set up elaborate governance structures. Even if it were, it is not clear that 18,000 police commissions necessarily should join some 14,000 school boards in the distinctly American experiment in hyperlocalized participatory government. Yet the problems of policing are hardly confined to major cities. Ferguson, after all, has a population of just over 20,000. ${ }^{283}$ And as Professor Monica Bell points out, poor rural communities may be particularly vulnerable to abusive policing. ${ }^{284}$

This suggests that in addition to making local police governance more effective, it is worth asking to what extent police decisions should be made locally at all. ${ }^{285}$ To be sure, so long as policing remains primarily a local

\footnotetext{
282 See, e.g., Privacy Advisory Commission, CITY OF OAKLAND, http://www2. oaklandnet.com/government/o/CityAdministration/d/PrivacyAdvisoryCommission/index.htm [https://perma.cc/T4BW-DFZ8].

283 U.S. DeP'T of Justice, Civil Rights Div., Investigation of the Ferguson Police DEPARTMENT 6 (2015).

284 See Bell, supra note 54, at 2136-37 (noting that "[t]he proliferation of many small police departments means that some neighborhoods can essentially become individual fiefdoms for certain officers," and that "[s]mall departments can also create various interjurisdictional inconsistencies ranging from the amount of training officers receive to the equipment available to keep themselves and civilians safe").

285 Professor William Stuntz has at times suggested that states ought to play a greater role, though his perspective on the issue has tended to shift over the years. Compare William J. Stuntz, Accountable Policing 8-11 (Harv. Pub. Law, Working Paper No. 130, 2006) https://papers.ssrn.com/sol3 /papers.cfm?abstract_id $=886170$ [https://perma.cc/WNJ3-UTGY] (arguing in favor of greater state and
} 
function, day-to-day decisions will continue to be made by local officials. But there are many decisions - concerning police policies, training requirements, data collection, and monitoring - that could be made at the state level. The federal government also could play a greater role, though federalism principles impose some constraints on what that role might be.

Both the federal government and the states already play some role in regulating local policing. The Constitution imposes national constraints on the manner in which officers exercise their authority to conduct searches and seizures and interrogate suspects. ${ }^{286}$ Federal statutes regulate certain aspects of policing, particularly around surveillance and digital privacy. ${ }^{287}$ The Department of Justice has investigated several dozen departments accused of engaging in a pattern or practice of unconstitutional policing, and in a subset of these investigations, has negotiated consent decrees mandating wide-ranging reforms. But as a number of scholars have pointed out, the Justice Department's resources are limited, and federal legislation is limited in scope and often badly out of date. ${ }^{288}$

States tend to be more active in the policing space. Legislatures in a number of states have passed laws regulating drones and other surveillance technologies, mandating the collection of traffic stop data, and governing practices such as strip searches and custodial interrogations. ${ }^{289}$ Every state has a commission on Police Officer Standards and Training (POST), which establishes the requirements for becoming a police officer and sets minimum standards for police training. ${ }^{290}$ The vast majority of state POSTs also have authority to strip officers of their law enforcement powers (called "decertification") upon conviction for certain crimes, and in some states, based on a finding of serious misconduct. ${ }^{291}$

federal involvement), with Stuntz, The Collapse of American CRiminal Justice 7-8 (2011) (arguing in favor of greater local control).

286 Mapp v. Ohio, 367 U.S. 643 (1961) (holding that both the protections of the Fourth Amendment and the exclusionary remedy apply to the states - and by extension, to local police).

28718 U.S.C. $\$ 2703$ (regulating police use of wiretaps).

288 See, e.g., Rachel Harmon, Limited Leverage: Federal Remedies and Policing Reform, 32 ST. LouIS U. PuB. L. REV. 33, 44-45 (2012) (citing limits of Section 14141 litigation); Orin S. Kerr, The Next Generation Communications Privacy Act, 162 U. PA. L. REV. 373, 373 (2014) (noting that the Electronic Communications Privacy Act "is widely regarded as outdated").

289 Friedman \& Ponomarenko, supra note 10, at 1844 (pointing to existing state laws in these areas); see also Law Enforcement Overview, NAT'L CONF. ST. Legislatures (June 19, 2018), http://www.ncsl.org/research/civil-and-criminal-justice/law-enforcement.aspx [https://perma.cc/CZ7X9LRH] (describing state regulation of several aspects of policing).

290 See H.B. $2071 \S 1$, 29th Leg. (Haw. 2018) (creating a POST and noting that Hawaii was the last state in the country to do so), https://www.capitol.hawaii.gov/session2018/bills/HB2071_HD2_.HTM [https://perma.cc/Q92Z-DH2X]. (2016).

${ }^{291}$ Roger Goldman, Importance of State Law in Police Reform, 60 ST. LoUIS U. L.J. 363, 381-82 
In other areas of government beyond policing, however, statewide entities, including legislatures and state-level agencies, play a much more expansive role. Although schools are run locally, state boards of education adopt curricular standards, graduation requirements, and performance metrics. ${ }^{292}$ In Texas, the state Commissioner for Education has the authority to bring a local school district under the control of an independent monitor if it fails to meet certain standards over a period of years. ${ }^{293}$ Most cities or counties likewise have their own social service agencies, but state departments set minimum standards for childcare facilities, foster care placements, and benefits determinations. ${ }^{294}$

In policing, too, states could do quite a bit more. State POSTs, for example, could be authorized to set minimum standards not only for training but also for substantive agency policies. The New Jersey Attorney General already has this authority and has adopted minimum standards on a variety of issues, including early warning systems, vehicle pursuits, less lethal weapons, and body-worn cameras. ${ }^{295}$ Many of these policies go well beyond the minimum requirements of constitutional law or even model policies adopted by law enforcement groups like the International Association of Chiefs of Police. ${ }^{296}$

To address more systemic failings - for example, around the use of force-states could set up audit bureaus to review policing practices in agencies that are too small to justify hiring a full-time inspector general. State attorneys general could augment the Justice Department's efforts by investigating local patterns of unconstitutional misconduct, which some

\footnotetext{
292 See, e.g., TEX. EDUC. CODE ANN. § 7.021 (2017).

293 Id. § 39A.002.

294 See, e.g., Child Care Regulations \& Policies, OfF. ChILD. \& Fam. SERvs., https://ocfs.ny.gov/main/childcare/daycare_regulations.asp [https://perma.cc/8GMV-KDMB]; Family Day Care Standards and Large Family Child Care Homes, Fla. Admin. Code \& Fla. Admin. Reg., https://www.flrules.org/gateway/ChapterHome.asp?Chapter=65C-20 [https://perma.cc/manage/create?folder=4050].

295 Attorney General Law Enforcement Directive No. 2018-1, Gurbir S. Grewal, Attorney General of New Jersey (Feb. 26, 2018), http://www.njdcj.org/agguide/directives/ag-directive-2018-1.pdf [https://perma.cc/8EBR-4ZTC].

296 See, e.g., Attorney General Law Enforcement Directive No. 2018-3, Gurbir S. Grewal, Attorney General of New Jersey (Mar. 20, 2018), http://www.njdcj.org/agguide/directives/ag-directive-2018-3.pdf [https://perma.cc/8EBR-4ZTC] (mandating all agencies to adopt an early warning system). Compare Attorney General Law Enforcement Directive No. 2018-1, Gurbir S. Grewal, Attorney General of New Jersey (Feb. 26, 2018), http://www.njdcj.org/agguide/directives/ag-directive-2018-1.pdf [https://perma.cc/8EBR-4ZTC] (directing law enforcement agencies to make body-worn video of officerinvolved shootings public at the completion of a preliminary investigation, which should typically take no more than 20 days), with INT'L Ass'N OF CHIEFS OF POLICE, BODY-WorN CAMERAS: MODEL POLICY (2014), http://www.theiacp.org/model-policy/wp-content/uploads/sites/ 6/2017/07/BodyWornCamerasPolicy.pdf [https://perma.cc/VP2L-UL8B] (making no mention of the release of video).
} 
already are authorized to do. ${ }^{297}$ States also could require local agencies to collect and publicize data about their enforcement practices, which could in turn strengthen existing local controls. ${ }^{298}$

One concern, of course, is that state-level intervention may fall prey to some of the same concerns with rulemaking identified in Parts I and II. State rules and regulations, for example, are unlikely to address those aspects of policing that are not particularly amenable to being regulated through rules in the first place-such as the twin problems of over- and underenforcement. Similarly, one would expect state-level auditors to focus primarily on matters of legal compliance-as opposed to the sorts of discretionary policy choices that end up disproportionately harming certain marginalized groups. It is difficult to imagine, for example, a state-level audit delving into a local policing agency's decisions around resource allocation or quality of life enforcement - both of which have been areas of interest for local IGs.

Another obvious concern with state-level regulation of policing is that traditionally, states have not been particularly hospitable grounds for police reform. ${ }^{299}$ Police unions and other law enforcement organizations are a powerful force in state-level politics. ${ }^{300}$ And states have at times done more to hamper effective regulation than to encourage it-for example, by adopting law enforcement officer bills of rights (LEBORs) that impose various restrictions on internal police investigations and limit the data that can be made public. ${ }^{301}$

Still, it is important to keep in mind that ordinary local politics has not been particularly conducive to effective regulation of policing either. The entire premise of Part III, consistent with much of the scholarship on agency design, is that it is possible to structure institutions in a way that mitigates these pathologies at least to some degree, and that legislatures may be more amenable to these structural changes than to legislating substantive reform. There are, of course, broader questions about whether state regulation would be preferable to the prevailing system of local control. The main point here

\footnotetext{
297 See, e.g., Simone Weichselbaum \& Tom Meagher, Sessions May Resist Federal Oversight of the Police, but There's Another Option, MARShall ProJ. (Feb. 5, 2017), https://www. themarshallproject.org/2017/02/05/sessions-may-resist-federal-oversight-of-police-but-there-s-anotheroption [https://perma.cc/EJF5-SQ5E].

298 See, e.g., Rachel Harmon, Why Do We (Still) Lack Data on Policing?, 96 MARQ. L. REV. 1119, 1122-28 (2012) (emphasizing the need for this sort of data).

299 See, e.g., id. at 1131-32 (noting that state and local politicians may not have the incentive to mandate local data collection).

300 Id.

301 Kevin M. Keenan \& Samuel Walker, An Impediment to Police Accountability? An Analysis of Statutory Law Enforcement Officers' Bills of Rights, 14 B.U. PUB. INT. L.J. 185, 212-14 (2005).
} 
is that in addition to focusing on agency design at the local level, scholars also could turn greater attention to the states.

\section{CONCLUSION}

The goal of this article has been two-fold: to highlight the many limits of rulemaking as a strategy for governing policing and, at the same time, to use those limits as a jumping off point to consider alternatives. Both the rulemaking moment of the 1960s and the rulemaking renaissance today were prompted by very real concerns both about the many problems of policing and the insufficiency of existing governance mechanisms to meaningfully address them. As Parts I and II made clear, there is a need for more and better rules around policing and also for greater transparency about the choices departments make and the effects they have. But we are unlikely to get there simply by extending APA-style rulemaking to local police. The problem, ultimately, is one of information and incentives - and until these two things change, rulemaking alone is likely to fall short, except around issues like police surveillance where the model does indeed seem to be a good fit. Part III proposed two possible changes to the status quo: regulatory intermediaries at the local level as well as greater state or federal control. The task going forward is to develop a much richer understanding of what it would take to make these alternatives work. 
N O R T H W ESTER N U N IVER S T Y LA W R E VIE W 